\title{
Highly siderophile elements mobility in the subcontinental lithospheric mantle beneath southern Patagonia
}

\author{
Santiago Tassara ${ }^{\mathrm{a}, *}$, José M. González-Jiménez ${ }^{\mathrm{b}}$, Martin Reich ${ }^{\mathrm{a}}$, Edward Saunders ${ }^{\mathrm{c}, \mathrm{d}}$, Ambre Luguet ${ }^{\mathrm{e}}$, \\ Diego Morata ${ }^{\mathrm{a}}$, Michel Grégoire ${ }^{\mathrm{f}}$, David van Acken ${ }^{\mathrm{g}}$, Manuel E. Schilling ${ }^{\mathrm{h}}$, Fernando Barra ${ }^{\mathrm{a}}$, \\ Geoff Nowell ${ }^{\mathrm{i}}$, Alexandre Corgne ${ }^{\mathrm{h}}$
}

a Department of Geology and Andean Geothermal Center of Excellence (CEGA), FCFM, Universidad de Chile, Plaza Ercilla 803, Santiago, Chile

b Departamento de Mineralogía y Petrología, Universidad de Granada, Facultad de Ciencias, Fuentenueva s/n 180002, Granada, Spain

c Division of Earth Sciences, School of Environmental and Rural Science, University of New England, Armidale, NSW 2351, Australia

d ARC Centre of Excellence for Core to Crust Fluid Systems/GEMOC, Macquarie University, NSW 2109, Australia

e Steinmann Institut für Geologie, Mineralogie und Paläontologie, Poppelsdorfer Schloss, 53115 Bonn, Germany

${ }^{\mathrm{f}}$ GET, CNRS-CNES-IRD-UPS, OMP, Toulouse University, 14 av. Edouard Belin, 31400 Toulouse, France

${ }^{g}$ University College Dublin, School of Earth Sciences, Science Centre West, Belfield, Dublin 4, Ireland

${ }^{\mathrm{h}}$ Instituto de Ciencias de la Tierra, Facultad de Ciencias, Universidad Austral de Chile, Valdivia 5090000, Región de Los Ríos, Chile

i Durham University, Department of Earth Sciences, Science Labs, Durham DH1 3LE, United Kingdom

\section{A R T I C L E I N F O}

\section{Article history:}

Received 28 April 2018

Accepted 24 June 2018

Available online 5 July 2018

\section{Keywords:}

Subcontinental lithospheric mantle

Metasomatism

Mobility

Highly siderophile elements

Base-metal sulphides

\begin{abstract}
A B S T R A C T
Peridotite xenoliths collected from alkali basalts in the Argentinian Patagonia reveal the existence of an ancient depleted Paleoproterozoic mantle that records a subsequent multistage metasomatic history. Metasomatism is associated with carbonatite-like melts that evolved, after variable melt/rock ratio interaction, towards $\mathrm{CO}_{2}$-rich and Na-bearing Mg-rich (mafic) silicate, and volatile-rich alkali silicate melts. High degrees of partial melting produced strongly depleted mantle domains devoid of base-metal sulphides (BMS). Moderate degrees of partial melting and later unrelated metasomatism produced a range of slightly depleted, slightly enriched, and strongly enriched mantle domains that preserve different types of BMS. Thus, six different BMS populations were identified including typical residual Type 1A BMS enriched in Os, Ir, and Ru relative to Pt, Pd, and Au located within primary olivine and clinopyroxene, and metasomatic Type 2A BMS that are relatively enriched in Pt, Pd, Au occurring as interstitial grains. Reworking of these two types of BMS by later metasomatism resulted in the formation of a new generation of BMS (Type $1 B$ and Type $2 B$ ) that are intimately associated with carbonate/apatite blebs and/or empty vesicles, as well as with cryptically metasomatised or metasomatic clinopyroxene. These newly formed BMS were re-enriched in Os, Pd, Au, Re and in semi-metal elements ( $\mathrm{As}, \mathrm{Se}, \mathrm{Sb}, \mathrm{Bi}, \mathrm{Te}$ ) compared to their Type $1 \mathrm{~A}$ and Type $2 \mathrm{~A}$ precursors. A third generation of BMS corresponds to Ni-Cu immiscible sulphide mattes entrained within Na-bearing silica under-saturated alkali melt. They occur systematically related to intergranular glass veins and exhibit distinctively near flat $\mathrm{Cl}$-chondrite normalised highly siderophile element patterns with either positive Pd (Type $3 A$ ) or negative Pt (Type $3 B$ ) anomalies. Our findings indicate that Os, Pd, Re and Au can be selectively transported by volatile-rich alkali silicate melts in the subcontinental lithospheric mantle. Moreover, the transport of sulphide mattes entrained in silicate melts is also an effective mechanism to produce HSE endowment in the SCLM and play an important role as precursors of fertile, metal-rich magmas that form ore deposits in the overlying crust.
\end{abstract}

(c) 2018 Elsevier B.V. All rights reserved.

\section{Introduction}

The six Platinum Group Elements (PGE: Os, Ir, Ru, Rh, Pt, Pd) plus gold $(\mathrm{Au})$, and rhenium ( $\mathrm{Re})$ comprise the highly siderophile elements (HSE). Given their strong chalcophile and siderophile affinity, these elements

\footnotetext{
* Corresponding author at: Departamento de Geología, Facultad de Ciencias Físicas y Matemáticas, Universidad de Chile, Plaza Ercilla \# 803, Santiago, Chile.

E-mail address: tassara.carlos.sant@ug.uchile.cl (S. Tassara).
}

tend to partition into sulphides or alloy phases (Luguet and Reisberg, 2016). Thus, they are increasingly used as tracers of the geochemical evolution of different layers of the solid Earth, and particularly along frontiers between the subcontinental lithospheric mantle (SCLM) and its underlying asthenosphere and overlying crust (Harvey et al., 2015, 2016).

There is agreement that during partial melting of the mantle, the most compatible HSE (IPGE: Os, Ir, Ru) are retained in the peridotitic residue within the structure of residual BMS or by forming platinumgroup minerals (PGM) (González-Jiménez et al., 2014; Lorand et al., 2008, 2010; Luguet et al., 2003, 2007; O'Driscoll and González-Jiménez, 
2016). These residual BMS, are typically monosulphide solid solution (mss) hosted in primary olivine or residual pyroxene, rich in IPGE, yielding relatively unradiogenic ${ }^{187} \mathrm{Os} /{ }^{188} \mathrm{O}$ ratios (Alard et al., 2002). In contrast, metasomatism can lead either to the removal or to the addition of HSE depending on the melt-fluid/rock ratio and the compositional nature of the metasomatic agents. Thus, a wide range of metasomatic agents have been proposed to explain the very different HSE systematics in SCLM peridotites (e.g., Lorand et al., 2013; Luguet et al., 2015). These include S-undersaturated OIB-like melts (Lorand et al., 2004; Saunders et al., 2016), volatile-rich silicate melts exsolved after percolation and reaction with the peridotite wall-rock or S-saturated melts (e.g., Grégoire et al., 1997; Moine et al., 2004); $\mathrm{CO}_{2}$-rich (i.e., carbonatite-like) melts (Akizawa et al., 2017; Saunders et al., 2015), and fluids derived from subduction zones (McInnes et al., 1999; Widom et al., 2003). Percolation of S-undersaturated melts usually removes BMS from the mantle and dilutes the whole-rock HSE concentrations in the peridotite whereas infiltration of S-saturated melts has the opposite effect producing the precipitation of Cu-Ni-rich sulphides (see Fig. 18 in Luguet and Reisberg, 2016). These Cu-Ni-rich BMS usually crystallise along grain boundaries or triple junctions of peridotite-forming silicates and oxides; they are typically rich in Pt, Pd, Re (and sometimes $\mathrm{Au}$ ) and semi-metals with more radiogenic ${ }^{187} \mathrm{Os} /{ }^{188}$ Os ratios (Alard et al., 2002; Harvey et al., 2010a, 2010b; Harvey et al., 2015; Harvey et al., 2016). However, BMS with HSE signatures similar to those that are typically originated by partial melting are being increasingly observed in metasomatic meltpockets occurring within mantle peridotite xenoliths elsewhere, questioning our understanding of HSE mobility in the SCLM (GonzálezJiménez et al., 2014; Hughes et al., 2017). Contrary to what is commonly thought, these observations claim against a direct relation between the microstructural position of the BMS and their trace element composition.

In the above scenario, a better understanding of the impact of the different metasomatic styles in the formation or modification of the HSE carriers is of critical importance to understanding how HSE are mobilized through the SCLM. This has important implications on how metals are sourced from the mantle to form ore deposits in the overlying crust (Begg et al., 2010; Griffin et al., 2013; Hronsky et al., 2012; Tassara et al., 2017). To date, few studies have addressed the relationship between HSE distribution in BMS and their petrography (e.g., Alard et al., 2000, 2005, 2011; Luguet et al., 2001, 2004; Luguet et al., 2007; Lorand et al., 2004; Delpech et al., 2012; GonzálezJiménez et al., 2014; Saunders et al., 2015, 2016; Van Acken et al., 2017) in order to define the fingerprints left at the grain-scale by each different metasomatic agent that percolated the SCLM. Despite these advances, there are significant gaps in knowledge that limit our understanding of the impact of metasomatism on HSE mobility. Particularly it is still debatable the effects that $\mathrm{CO}_{2}$-rich melts have in mobilizing HSE in the SCLM (Akizawa et al., 2017; Hughes et al., 2017; Saunders et al., 2015).

This study aims at defining the mechanisms of mobility of HSE in the mantle by identifying fingerprints left by the different metasomatic agents that infiltrated and modified the composition of the southern Patagonian SCLM. To achieve this goal, we selected a suite of 23 peridotite xenoliths from three key localities from southern Patagonia representative of volumes of mantle having experienced significant melt extraction and subsequent metasomatism. We performed (i) major and trace elements analyses including HSE and ${ }^{187} \mathrm{Os} /{ }^{188} \mathrm{Os} \mathrm{composi-}$ tions of the whole-rock, and (ii) major and trace elements analyses in silicates and non-silicates phases and HSE and semi-metals analyses in BMS. We refine previous knowledge about HSE fingerprints left by melt depletion and the multistage metasomatism in these peridotites, providing valuable insights into the mechanisms of HSE mobility in the SCLM beneath southern Patagonia. The new information provided here is of particular relevance to understanding the mechanisms of HSE enrichment in the SCLM, the formation of HSE-rich magmas, and the link between the SCLM and the formation of ore deposits in the overlying crust.

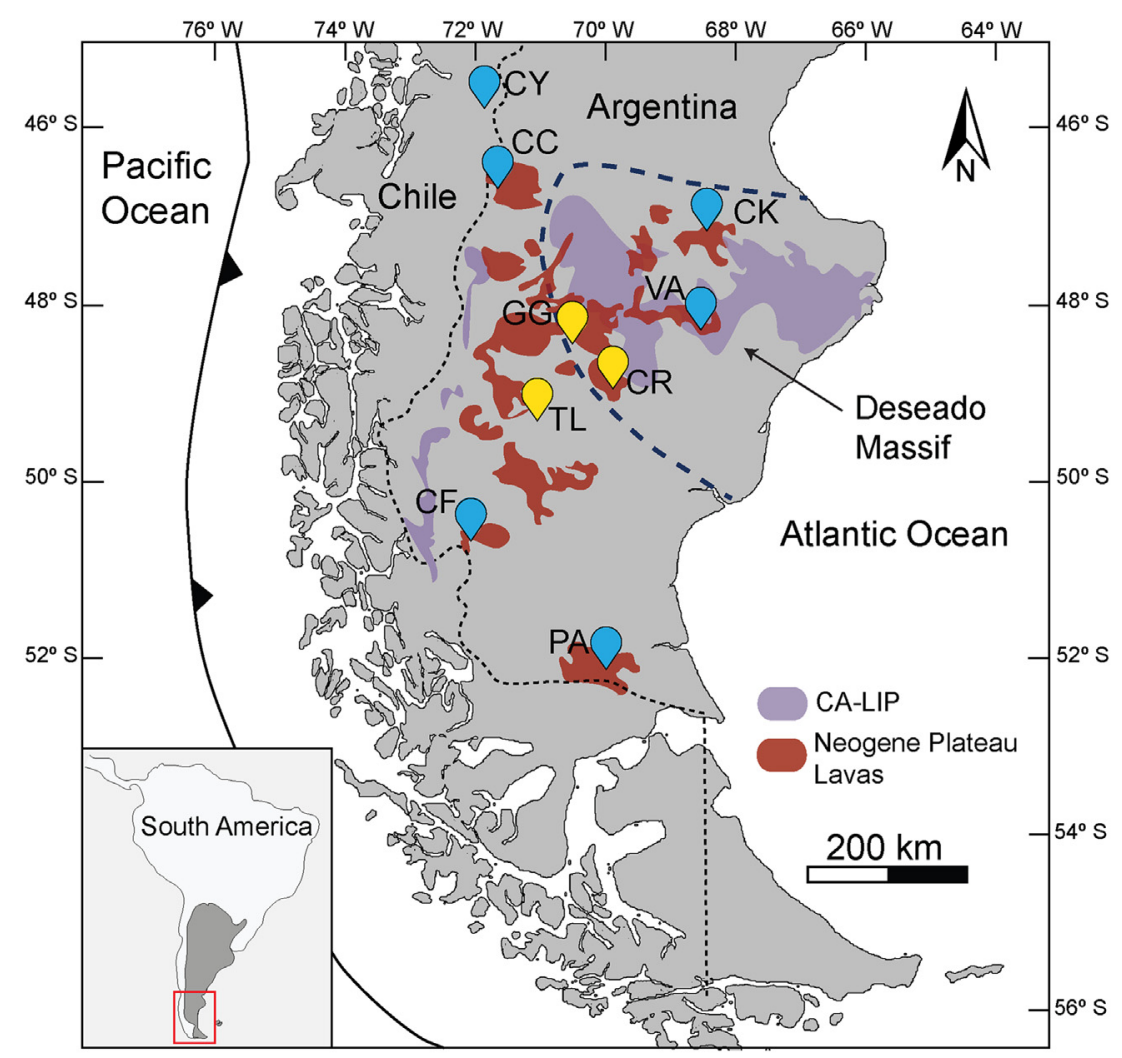




CF: Cerro del Fraile; PA: Pali Aike. CA-LIP: Chon Aike large igneous province. 


\section{Geological background}

The Patagonia region in southern South America comprises the Andean and extra-Andean (back-arc) territory of southern Chile and Argentina (Fig. 1), and its geological evolution is closely related to the subduction of the Nazca and Antarctic plates since the Jurassic (Ramos and Aleman, 2000). In the Andean Patagonia, the Southern Volcanic Zone (SVZ) and Austral Volcanic Zone (AVZ), related to the subduction of the Nazca and Antarctic plates respectively, are separated by a volcanic gap caused by the subduction of the Chile-Ridge (Forsythe et al., 1986). The back-arc region in Argentina, on the other hand, is characterised by Middle to Late Jurassic volcanism that gave rise to the Chon Aike Large Igneous Province (CA-LIP). The CA-LIP represents a period of extensive volcanism developed during the initial stages of the break-up of Gondwana (187-144 Ma) and comprises an early ( $188 \mathrm{Ma})$ tholeiitic stage caused by the thermal impact of the Karoo mantle plume, followed by a late $(\sim 155 \mathrm{Ma})$ calc-alkaline stage formed after the influence of a subduction zone at the western margin of Gondwana (Pankhurst et al., 2000). The late stage of the CA-LIP is genetically linked to the formation of the Deseado Massif auriferous province in southern Patagonia, the world's southernmost metallogenic region. The Deseado Massif auriferous province was developed as a result of the combination of the thermal impact caused by the impingement of the Karoo plume followed by the influence of a subduction zone (Tassara et al., 2017).

During the Miocene, the subduction of the Chile-Ridge promoted the opening of a slab window that allowed the upwelling of asthenospheric melts that gave rise to an extensive Neogene volcanism (Gorring et al., 1997), characterised by an eastward decreasing of the slab component (Gorring and Kay, 2001; Stern et al., 1990). The latter includes Miocene ( 14 to $5 \mathrm{Ma}$ ) plateau basalts of tholeiitic to alkaline composition and Pliocene ( 6 to $2 \mathrm{Ma}$ ) post-plateau alkaline, OIB-like basalts occurring in volcanic centres. The origin of the plateau basalts was ascribed to asthenospheric sources enriched by a weak plume that was related to the opening of the slab window (D'Orazio et al., 2001) whereas the post-plateau alkaline basalts are related to thermal perturbations induced by the subducted slab in asthenospheric levels of the mantle wedge (Stern et al., 1990). In the southernmost part of Argentina, the Pliocene post-plateau basalts sampled peridotite xenoliths from the SCLM beneath the Deseado Massif auriferous province. Numerous scoria cones, lava flows and pyroclastic deposits form nine different xenolithsampling localities in southernmost Patagonia (Fig. 1).
Recent studies focused on the Os isotopic composition of peridotite xenoliths from southern Patagonia and determined the existence of a Mesoproterozoic-to-Paleoproterozoic depleted SCLM (1.3-1.9 Ga for Tres Lagos and 2.5 Ga for Pali Aike; Fig. 1) which was variably modified by the infiltration of metasomatic melts or fluids, although the timing of metasomatism remains unclear (Mundl et al., 2015; Ntaflos et al., 2007; Schilling et al., 2008; Schilling et al., 2017). The metasomatic agents identified in the SCLM beneath southern Patagonia include: (1) carbonatite-like melts and nepheline-normative alkali basalt mainly in Gobernador Gregores locality (Aliani et al., 2009; Gorring and Kay, 2000; Laurora et al., 2001; Rivalenti et al., 2004; Scamberulli et al., 2009), (2) silicate melts in the Tres Lagos locality, although not clearly determined (Ntaflos et al., 2007), and (3) slab-derived fluids in the Coyaique locality (Jalowitzki et al., 2017; Fig. 1). Additional studies have recognised the percolation of slab-derived reduced $(\triangle \mathrm{FMQ}-0.2$ to -0.4 ) fluids in peridotites from Cerro del Fraile and asthenospherederived melts in Pali-Aike (Wang et al., 2007, 2008).

\section{Results}

\subsection{Sample description}

We studied 23 peridotite xenoliths from the Tres Lagos, Cerro Redondo, and Gobernador Gregores localities (Fig. 1). The peridotite dataset investigated here include 18 lherzolites, 2 harzburgites, 1 dunite, and 2 wehrlites (Fig. 2) representative of the variable petrological history previously described in southern Patagonia. We performed whole rock major and trace elements analysis by X-ray fluorescence and ICP-MS, as well as HSE and ${ }^{187} \mathrm{Os} /{ }^{188}$ Os determinations by SF-ICPMS and N-TIMS respectively. In addition, we determined the major and trace elements composition of silicates and sulphide phases by electron microprobe and LA-ICP-MS. The analytical procedures are described in detail in Appendix 1 and the results, along with a complete list of the samples used in this study is provided in Appendices 2 to 5 .

The studied peridotite xenoliths vary in size from 6 to $30 \mathrm{~cm}$ and exhibit granular and porphyroblastic (Tres Lagos and Cerro Redondo; Fig. 2), or microgranular textures with strain-free silicates (Gobernador Gregores; Fig. 2). All peridotites were equilibrated in the spinel stability field and belong to the Cr-diopside series of Wilshire and Shervais (1975). In addition to the typical peridotitic silicates and spinel, their mineral assemblage contains accessory metasomatic minerals such as
A

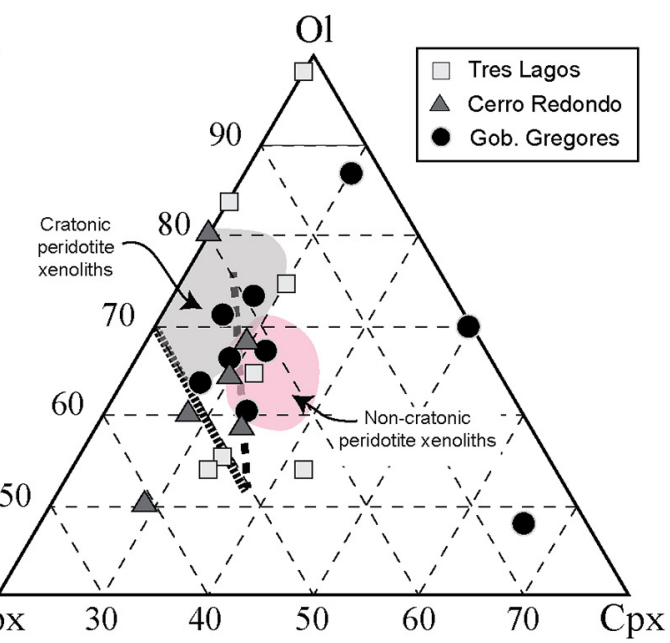


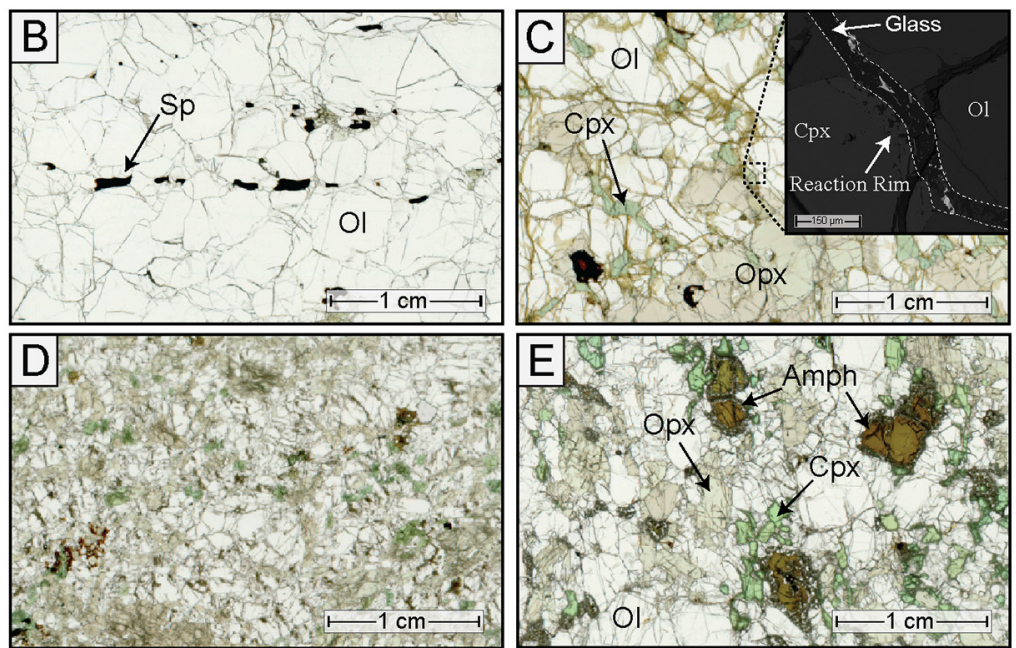

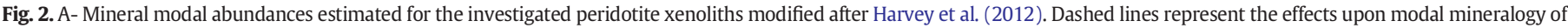



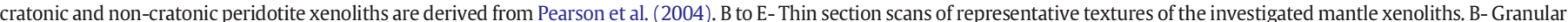

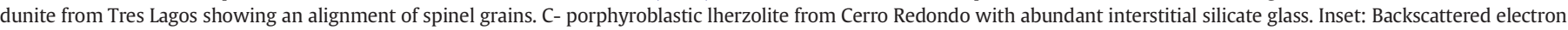

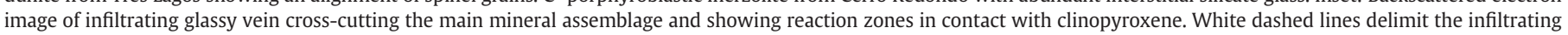
glassy vein containing BMS, apatites and Ti-oxides. D- microgranular lherzolite from Gobernador Gregores. E- Amphibole bearing granular lherzolite from Gobernador Gregores. 
amphibole, phlogopite, carbonates and apatite (Fig. 3). Amphibole and phlogopite form aggregates of up to $2 \mathrm{~mm}$ located between olivine and pyroxene as well as veins or layers of up to $8 \mathrm{~mm}$ (Gobernador Gregores, Fig. 3A, B). Carbonates are found as isolated crystals of up to $700 \mu \mathrm{m}$ commonly located at the triple junction among primary silicates sometimes associated with BMS (i.e., Tres Lagos and Gobernador Gregores; Fig. 3C, D). Apatite fills interstices between main silicates (Tres Lagos; Fig. 3E) or is included within clinopyroxene or in contact with empty vesicles next to metasomatic amphibole (lherzolites and wehrlites from Gobernador Gregores; Fig. 3F, G). Other metasomatic minerals are secondary generations of clinopyroxene and olivine identified by their chemistry and cross-cutting relationships in the peridotites from Gobernador Gregores (Fig. 3H, I).

Glass occurs either as (1) a discontinuous system of melt pockets surrounding hydrous minerals such as amphibole (Gobernador Gregores), or (2) an interconnected network of veins cross-cutting the peridotite with sharp contacts against the silicate matrix (Cerro Redondo, Fig. 2C). The interstitial glass was never observed in connection with the enclosing host basalt. Overall, it constitutes $<3$ modal \% of the studied peridotites, except for some lherzolites from Cerro Redondo where it reaches up to 7 modal \%. The interstitial silicate glass from Cerro Redondo samples is commonly altered to zeolites, although it still preserves an unaltered mineral assemblage of incompletely reacted olivine and pyroxenes together with armalcolite $[(\mathrm{Mg}$, $\left.\mathrm{Fe}^{2+}\right) \mathrm{Ti}_{2} \mathrm{O}_{5}$ ], ilmenite, Na-K-feldspar, and apatite that is contained within the glass and likely formed after cooling in the lithospheric mantle (Tassara et al., 2017).

\subsection{Whole-rock chemistry: major and trace elements}

The 23 spinel peridotites investigated range from strongly depleted harzburgites and dunites to fertile lherzolites, and strongly enriched lherzolites and wehrlites (Fig. 2-4; Appendix 2). This broad compositional variation is reflected in the $\mathrm{MgO}$ vs. $\mathrm{Al}_{2} \mathrm{O}_{3}$ plot (Fig. $4 \mathrm{~A}$ ) and in the progressive increase in $\mathrm{Ca}$ from dunites and harzburgites
(0.1-1 wt\%) to lherzolites (0.9-3.5 wt\%) and the wehrlites (up to $8.1 \mathrm{wt} \%$ ) (Fig. 4B), which is accompanied by a decrease in the MgO content (Appendix 2). The higher $\mathrm{CaO}$ content in the most fertile wehrlites and lherzolites is related to the higher abundance of clinopyroxene, amphibole, carbonates and apatite in those samples (Fig. 3). The $\mathrm{CI}$ chondrite-normalised trace element patterns of the studied peridotite xenoliths define four distinct groups presented below:

\subsubsection{Group 1 (strongly depleted peridotites)}

These peridotites are characterised by a low trace element content (i.e., $0.2 \mathrm{Gd}$ - $1.7 \mathrm{La}$ x CI chondrite) and a U-shaped CI chondritenormalised REE pattern (Fig. 5A). They display a (La/Yb) (subscript "n" = normalised to CI chondrite after McDonough and Sun (1995)) ratio between 1.65 and 4.76, a strong middle REE (MREE) depletion and a slightly positive Ti anomaly (i.e., $(\mathrm{Ti} / \mathrm{Eu})_{\mathrm{n}}>1<(\mathrm{Ti} / \mathrm{Gd})_{\mathrm{n}}$; in this case $\sim 1.7$ for both) (Fig. 5B). This group comprises two clinopyroxenefree harzburgites (CR-01 and TL-2-1) and one clinopyroxene free-dunite (TL-05) from Cerro Redondo and Tres Lagos respectively (Appendix 2).

\subsubsection{Group 2 (slightly depleted peridotites)}

These peridotites have a low trace element contents $(0.3 \mathrm{La}-1.4 \mathrm{Lu}$ $\mathrm{xCI}$ chondrite $)$ and a slightly positive $\left((\mathrm{La} / \mathrm{Yb})_{\mathrm{n}}=0.36-0.4\right)$ to flat $\left((\mathrm{La} / \mathrm{Yb})_{\mathrm{n}}=0.8-1.1\right)$ REE pattern (Fig. $\left.5 \mathrm{C}\right)$. In addition, these samples show a slight decrease in high field strength element concentrations (HFSE: Nb, Ta, Zr, Hf), a slight negative Ti anomaly ((Ti/Eu $)_{\mathrm{n}}$ and (Ti/ $\left.\mathrm{Gd})_{\mathrm{n}} \sim 0.8\right)$ and a relative positive $\mathrm{U}$ anomaly $\left((\mathrm{U} / \mathrm{Th})_{\mathrm{n}}=0.8-8.6\right)$. They also display lower than the primitive mantle (McDonough and Sun, 1995) concentrations of large ion lithophile elements (LILE: e.g., Rb, Ba, Sr) (Fig. 5D; Appendix 2). This group includes five lherzolites from Cerro Redondo (samples CR-02, CR-03, CR-07, CR-08, and CR-09) and one lherzolite from Tres Lagos (sample TL-2-3); all of them with $<14 \%$ modal clinopyroxene and no metasomatic accessory minerals (Appendix 2).
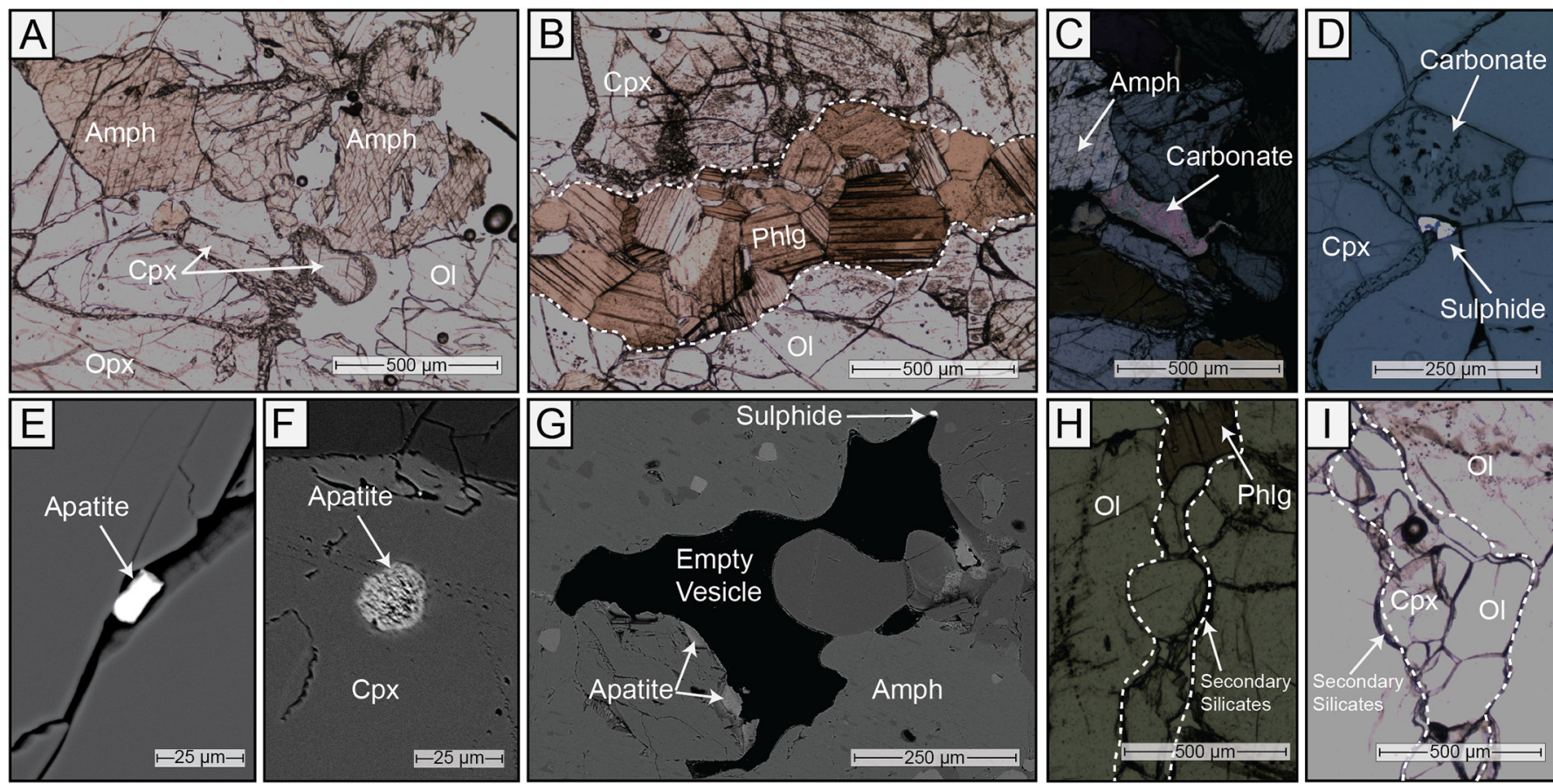

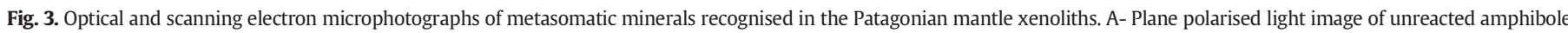

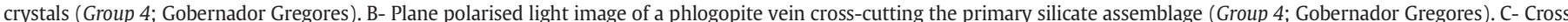

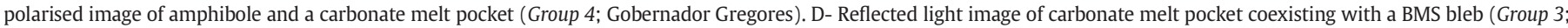

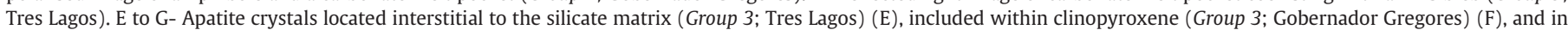
contact with an empty vesicle close to a metasomatic amphibole (Group 4; Gobernador Gregores). 

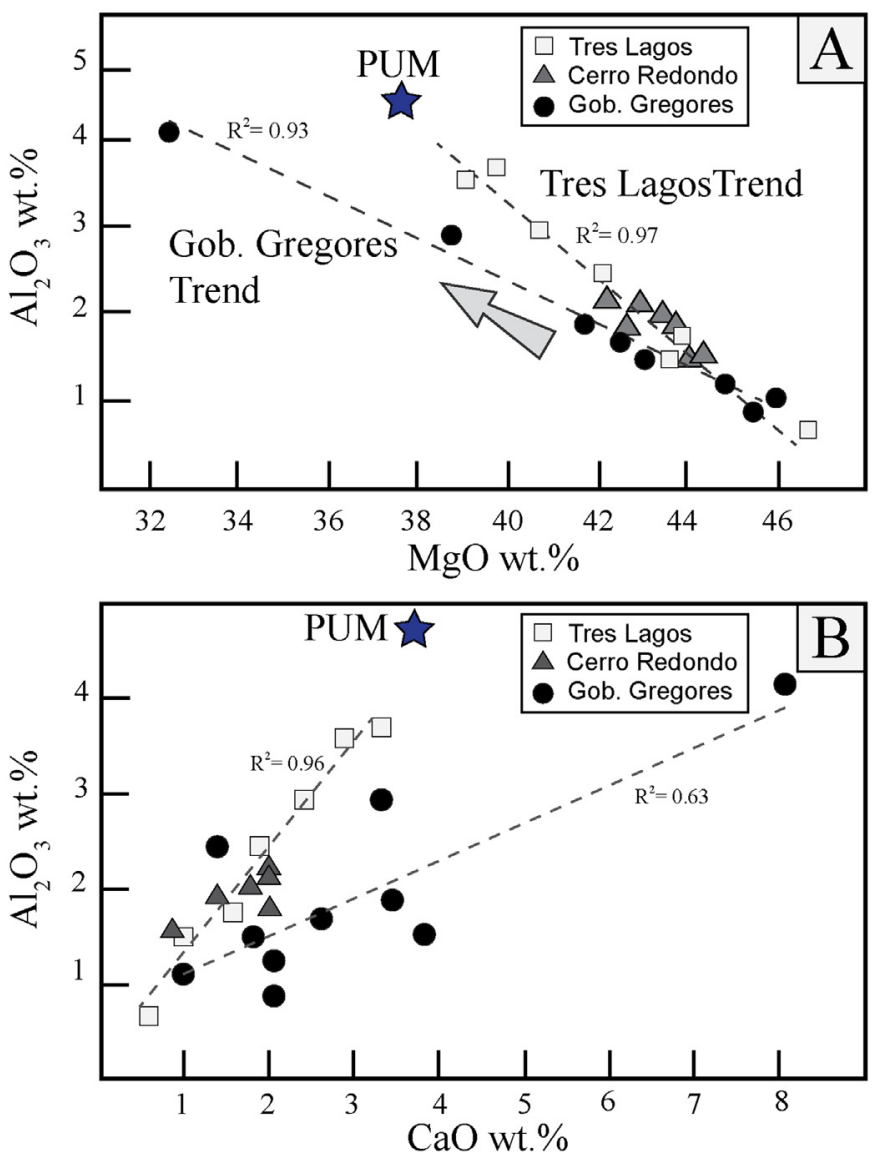

Fig. 4. Major element variations for southern Patagonian peridotite xenoliths. Dashed lines correspond to the inferred trends for the variable transformation occurred between the refractory dunite/harzburgites and variably depleted/enriched lherzolites and lherzolites. PUM: Primitive upper mantle (McDonough and Sun, 1995).

\subsubsection{Group 3 (slightly enriched peridotites)}

These peridotites have trace element contents up to 5 times the $\mathrm{CI}$ chondrite (e.g., La) values and show a nearly flat to depleted heavy REE (HREE) to MREE pattern (Fig. 5E). They are characterised by a suprachondritic $(\mathrm{La} / \mathrm{Ce})_{\mathrm{n}}(1.22-1.94)$ ratio and a noticeable LREE enrichment $\left((\mathrm{La} / \mathrm{Yb})_{\mathrm{n}}=0.8-5.44\right)$ in some of the samples (Fig. 5E). The LREE enrichment is accompanied by a slight increase in $\mathrm{Ba}$ and $\mathrm{Sr}$ compared to the Group 2 peridotites, which is decoupled from the HFSE as evidenced in the slight negative $\mathrm{Hf}, \mathrm{Zr}$, Nb, and Ta anomalies (Fig. 5F). This group consists of 4 lherzolites from Tres Lagos (TL-01, TL-03, TL-06, and TL-08) and 3 lherzolites from Gobernador Gregores (GG-05, GG-10, and GG-13; Appendix 2).

\subsubsection{Group 4 (strongly enriched peridotites)}

The peridotites from this group exhibit the highest concentrations of trace elements with values of trace elements (up to 30 times the CI chondritic values for LREE and 100 times for $\mathrm{Nb}$ and $\mathrm{Ta}$ ) and are characterised by convex upward REE distribution with extreme LREE enrichment $\left((\mathrm{La} / \mathrm{Yb})_{\mathrm{n}}=4.63-10.22\right)$ (Fig. 5G; Appendix 2). In this group, the three samples having the highest LREE/HREE fractionation display strong positive anomalies of $\mathrm{Ta}$ and $\mathrm{Nb}$, whereas the least enriched of the group display variable $\mathrm{Nb} / \mathrm{Ta}$ ratios (Fig. $5 \mathrm{H}$ ). All samples display slight to strong $\mathrm{Hf}, \mathrm{Zr}$, and Ti negative anomalies (Fig. $5 \mathrm{H}$ ). Interestingly, these peridotites contain the larger modal abundance of metasomatic minerals including amphibole, phlogopite, carbonates and apatite. This group of samples include five lherzolites (GG-01-A, GG-02, GG-03, GG-07, and GG-14) and 2 wehrlites (GG-17; GG-01B) from Gobernador Gregores.

\subsection{Whole-rock HSE and Re-Os isotopic signatures}

Whole-rock HSE concentrations and Re-Os isotopic ratios were determined for 21 samples and are reported in Appendix 3. The peridotite xenoliths show HSE systematics that broadly corresponds with the lithological groups defined above and are described below (Fig. 6).

The Group 1 peridotites have bulk-rock HSE contents between 13.3 and 28.3 ng.g ${ }^{-1}$, defining a HSE pattern depleted in all elements relative to the $\mathrm{CI}$ chondrite, except for a slight Ru positive anomaly in sample CR-01 (Fig. 6A; Appendix 3). The Group 2 peridotites have the highest total HSE abundances (18.84-36.80 ng.g ${ }^{-1}$ ) of all groups and display flat $\mathrm{CI}$ chondrite-normalised HSE patterns, where the Os-Pt segments remain near the PUM values and the Pt-Re segments diverge from the PUM (Fig. 6B; Appendix 3). Noticeably, sample CR-09 has the highest Re content $(1.77 \times$ PUM) (Fig. 6B). The Group 3 peridotites have low total HSE abundances (10.05-8.91 ng.g ${ }^{-1}$ ) and display convex upwards shaped CI chondrite-normalised HSE patterns (Fig. 6C). This group shows systematic enrichment in Pd relative to Pt, but below the PUM, excepting sample GG-13 (Fig. 6C; Appendix 3). The Group 4 peridotites show the lowest total HSE concentrations of all groups (4.4 and 20.9 ng. ${ }^{-1}$ ). Their CI chondrite-normalised HSE patterns are characterised by a convex upward (samples GG-02, GG-07, and GG-14) or flat to positive-sloped shapes (peridotites GG-01-A, GG-01-B, GG-03, and GG-17; Fig. 6D; Appendix 3).

The ${ }^{187} \mathrm{Os} /{ }^{188} \mathrm{Os}$ ratios of the studied peridotites are unradiogenic $(0.116330-0.127191)$ with respect to the PUM $\left({ }^{187} \mathrm{Os} /{ }^{188} \mathrm{Os}=0.1296 \pm\right.$ 0.0008; Meisel et al., 2001), except for sample GG-01-B (Group 4) which has a highly radiogenic ${ }^{187} \mathrm{Os} /{ }^{188} \mathrm{Os}$ composition $(0.215985)$. In the $\mathrm{Al}_{2} \mathrm{O}_{3}$ vs. ${ }^{187} \mathrm{Os} /{ }^{188} \mathrm{Os}$ plots, the samples define a broad/loose positive trend (Fig. 7A; Appendix 3). Overall, the peridotites show no systematic correlation between the ${ }^{187} \mathrm{Os} /{ }^{188} \mathrm{Os}$ and the ${ }^{187} \mathrm{Re} /{ }^{188} \mathrm{Os}$ ratio, and most samples plot below the Enstatitic Chondritic Reservoir (ECR; ${ }^{187} \mathrm{Os} /{ }^{188} \mathrm{Os}=0.1281$, ${ }^{187} \mathrm{Re} /{ }^{188} \mathrm{Os}=0.421$; Walker et al., 2002) values in ${ }^{187} \mathrm{Os} /{ }^{188} \mathrm{Os}$ vs. ${ }^{187} \mathrm{Re} /{ }^{188}$ Os graphs (Fig. 7B). Only two samples are out of this general rule with coupled radiogenic ${ }^{187} \mathrm{Os} /{ }^{188} \mathrm{Os}$ and ${ }^{187} \mathrm{Re} /{ }^{188} \mathrm{Os}$ (wehrlite GG-01-B of Group 4) and uncoupled suprachondritic ${ }^{187} \mathrm{Re} /{ }^{188} \mathrm{Os}$ and subchondritic ${ }^{187} \mathrm{Os} /{ }^{188} \mathrm{Os}$ (CR-09 of Group 2). The ${ }^{187} \mathrm{Os} /{ }^{188} \mathrm{Os}$ ratios are uncorrelated with the whole-rock Os content (Fig. 7C).

Rhenium-depletion $\left(T_{\mathrm{RD}}\right)$ model ages and $T_{\mathrm{RD}}$ model ages vary from 1.66 to $0.13 \mathrm{Ga}$, except one wehrlite for which no meaningful model age can be derived (GG-01B: ${ }^{187} \mathrm{Os} /{ }^{188} \mathrm{Os} \sim 0.215985$; Fig. 7D; Appendix 3). The Group 1 peridotites yielded a Mesoproterozoic $T_{\mathrm{RD}}$ model age $(1.45 \mathrm{Ga})$ for the Cerro Redondo sample and an early Palaeozoic $(0.34 \mathrm{Ga})$ for the Tres Lagos peridotite. The Group 2 samples yielded middle Mesoproterozoic to late Paleoproterozoic $T_{\mathrm{RD}}$ ages (1.23 to $1.13 \mathrm{Ga}$ ) except for sample TL-2-3 that yielded a younger age $(0.51 \mathrm{Ga})$. The Group 3 samples have Mesoproterozoic to Neoproterozoic ages ( 0.9 to $0.13 \mathrm{Ga}) T_{\mathrm{RD}}$ model ages and the Group 4 samples have Paleoproterozoic to Neoproterozoic (1.66 to 0.62) $T_{\mathrm{RD}}$ model ages (Fig. 7D; Appendix 3).

The Group 1 peridotites and the Group 4 (except samples GG-02, GG17 , and GG-01-B) exhibit $T_{\mathrm{RD}}$ ages $\approx T_{\mathrm{MA}}$ ages with an offset lesser than $0.18 \mathrm{Ga}$ and $0.23 \mathrm{Ga}$ respectively. In contrast, a significant discrepancy exists between the $T_{\mathrm{RD}}$ and $T_{\mathrm{MA}}$ ages in the Group 2 (offset $=0.1-1.19 \mathrm{Ga}$ ) and the Group 3 peridotites (offset $=0.11-0.89 \mathrm{Ga}$ ). Unrealistic $T_{\mathrm{MA}}$ ages are also identified in the most metasomatised wehrlite (GG-01-B) and lherzolite (GG-17) whereas sample GG-02 shows a much older $T_{\mathrm{MA}}$ age (2.46 Ga) (Appendix 3).

\subsection{Mineral chemistry: olivine and pyroxenes}

\subsubsection{Strongly depleted peridotites (group 1)}

Orthopyroxene and olivine from this group show the most refractory composition of all samples, consistent with their clinopyroxenefree nature. Orthopyroxene shows a $\mathrm{Mg} \#([\mathrm{MgO} /(\mathrm{FeO}+\mathrm{MgO}) * 100]$ in molar proportions) ranging from 91.8 to 92.4 , and a $\mathrm{Na}_{2} \mathrm{O}$ content below the detection limit ( $0.02 \mathrm{wt} \%$ ). Consistently, $\mathrm{Al}_{2} \mathrm{O}_{3}$ and $\mathrm{TiO}_{2}$ 

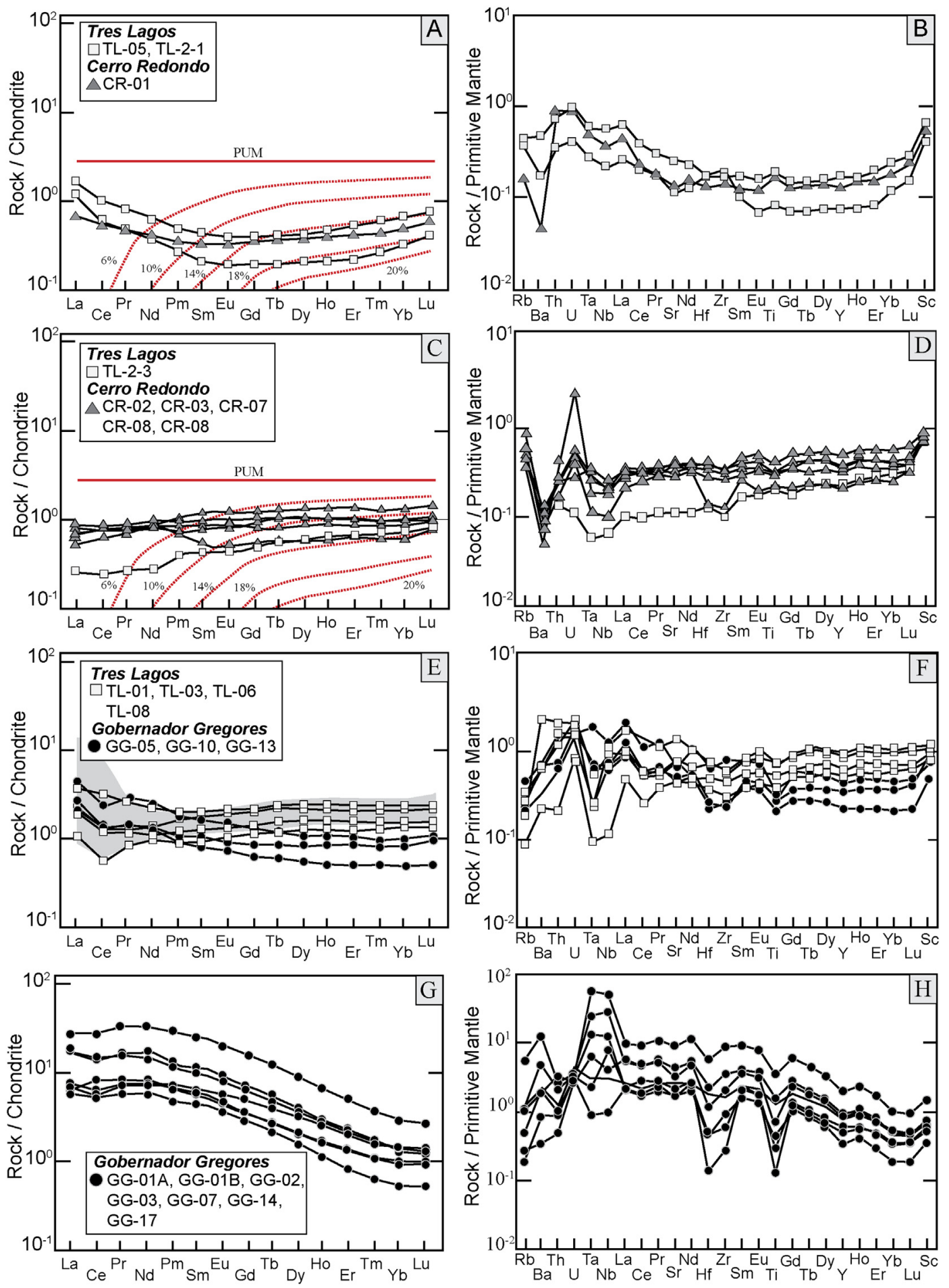

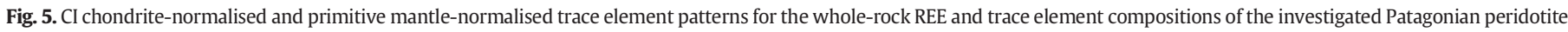

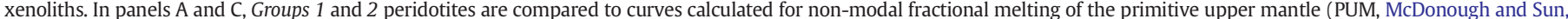

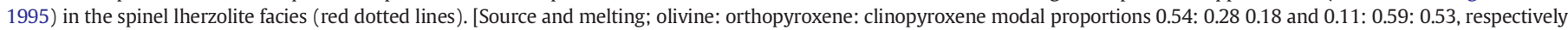

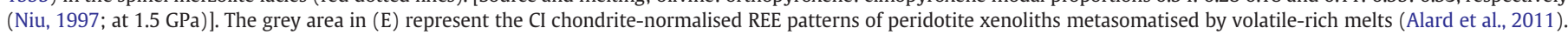
Normalising values after McDonough and Sun (1995).

contents of orthopyroxene are also low being at most 3.21 and $0.07 \mathrm{wt} \%$ respectively (Appendix 4). Olivine has a Mg\# ranging from 91 to 91.5, $\mathrm{NiO}$ contents between 0.36 and $0.43 \mathrm{wt} \%$, and variable $\mathrm{CaO}$ contents (up to 0.07 wt\%) (Appendix 4).

\subsubsection{Slightly depleted peridotites (group 2)}

Clinopyroxene from this group is characterised by a Mg\# between 90.3 and 93.6 and its major element composition are summarised in Table 1.
This clinopyroxene (hereafter Cpx1) shows depletion in the most incompatible LREE and overall low contents of LILE and HFSE (Fig. 8A, B; Table 1). Orthopyroxene has a refractory composition characterised by a $\mathrm{Mg} \#$ from 91 to 91.7 and a $\mathrm{Na}_{2} \mathrm{O}$ content $<0.07 \mathrm{wt} \%$. Consistently, $\mathrm{Al}_{2} \mathrm{O}_{3}$ and $\mathrm{TiO}_{2}$ content of Group 2 orthopyroxene is also (i.e., $<3.84$ and 0.13 , respectively) (Appendix 4). Olivine has $\mathrm{Mg} \#$ values that range from 90.5 to $91.5, \mathrm{NiO}$ contents between 0.3 and $0.5 \mathrm{wt} \%$ and $\mathrm{CaO}$ contents ranging from below detection limit (0.01 wt\%) to $0.13 \mathrm{wt} \%$ (Appendix 4). 

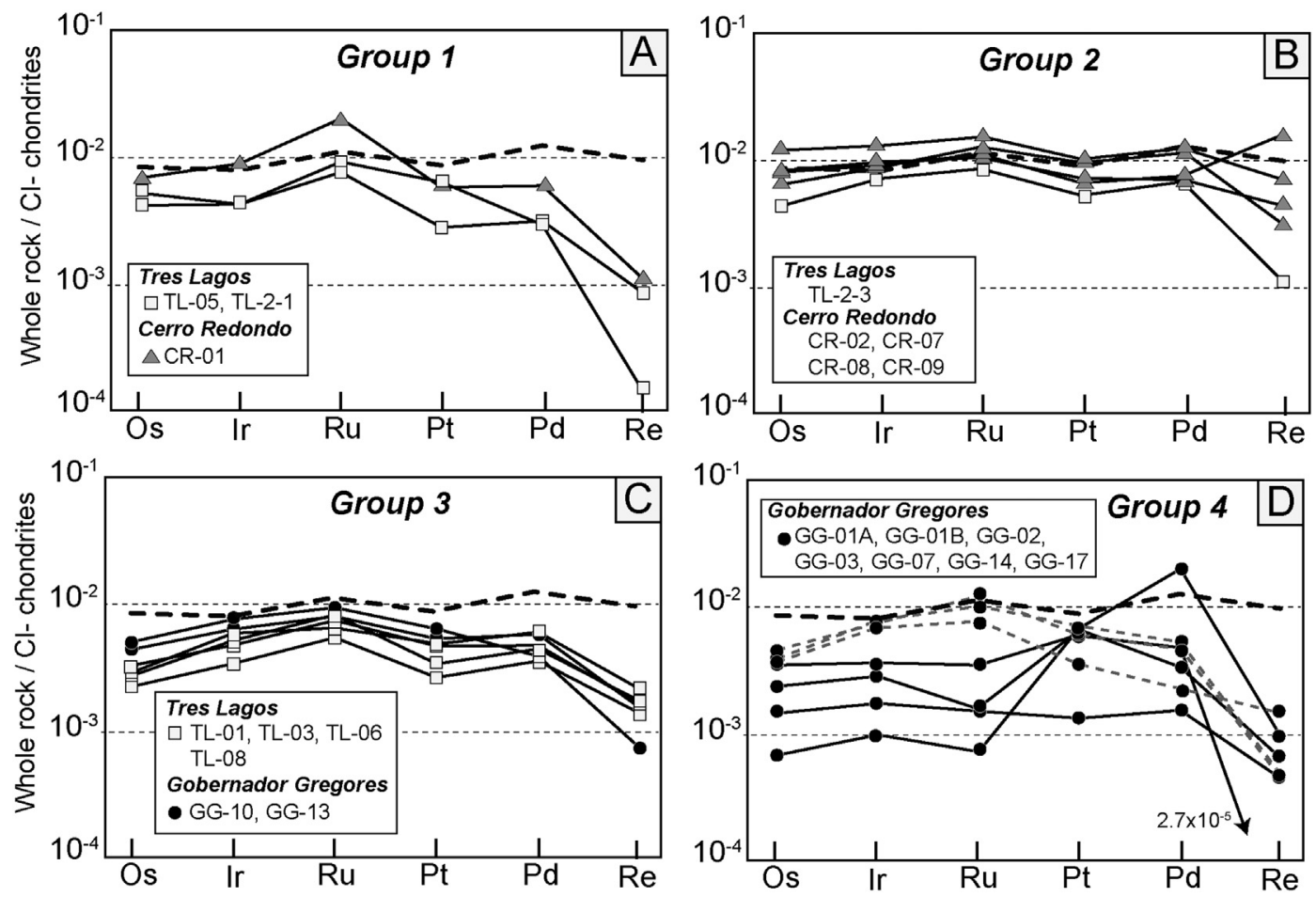

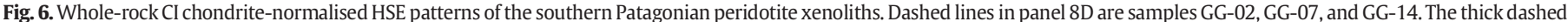

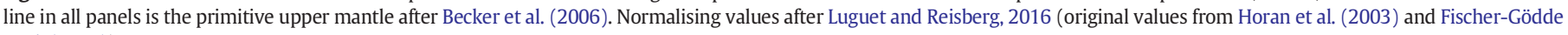
et al. (2010)).


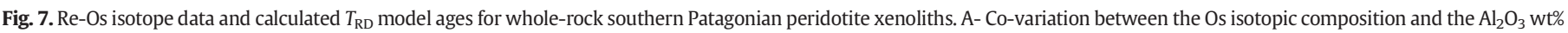

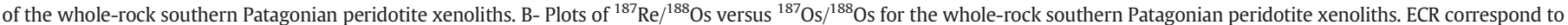

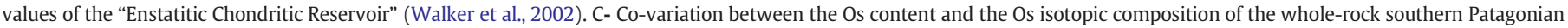

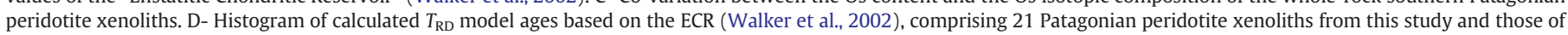
Mundl et al. (2015) and Schilling et al. (2017). 
Table 1

Summarised compositional features of the different clinopyroxene types.

\begin{tabular}{|c|c|c|c|c|c|c|c|}
\hline \multirow[t]{2}{*}{ Group } & \multicolumn{2}{|l|}{ Cpx1 } & \multirow{2}{*}{$\frac{C p \times 2}{3}$} & \multirow{2}{*}{$\frac{C p \times 3}{3}$} & \multirow{2}{*}{$\frac{C p \times 4}{4}$} & \multirow{2}{*}{$\frac{C p \times 5}{4}$} & \multirow{2}{*}{$\frac{\text { Cpx6 }}{4}$} \\
\hline & 2 & 3 & & & & & \\
\hline Mg\# & $90.3-93.6$ & $93-94$ & $91.4-92.6$ & $90.5-91.6$ & $92.2-92.6$ & $90.77-92.15$ & $86.7-90.6$ \\
\hline $\mathrm{Al}_{2} \mathrm{O}_{3}$ & $2.27-7.47$ & $2.72-4.33$ & $4.50-5.50$ & $5.81-6.43$ & $4.13-5.44$ & $5.06-5.82$ & $3.91-8.86$ \\
\hline $\mathrm{Cr}_{2} \mathrm{O}_{3}$ & $0.87-1.39$ & $0.68-1.45$ & $0.91-1.23$ & $0.64-0.89$ & $2.18-3.20$ & $1.85-2.04$ & $0.70-1.49$ \\
\hline $\mathrm{TiO}_{2}$ & $0.18-0.72$ & $0.20-0.23$ & $0.19-0.27$ & $0.42-0.58$ & $0.27-0.41$ & $0.07-0.31$ & $0.64-1.06$ \\
\hline $\mathrm{NaO}$ & $0.46-1.62$ & $0.46-0.56$ & $1.36-1.49$ & $1.59-1.77$ & $0.96-0.78$ & $1.32-2.55$ & $0.81-3.52$ \\
\hline$(\mathrm{La} / \mathrm{Ce})_{\mathrm{n}}$ & $0.50-0.97$ & $0.60-0.73$ & $1.05-2.22$ & $1.46-1.82$ & $0.56-0.75$ & $0.73-0.80$ & $0.61-1.00$ \\
\hline$(\mathrm{La} / \mathrm{Yb})_{\mathrm{n}}$ & $0.02-0.61$ & $0.24-0.53$ & $2.23-3.83$ & $0.83-1.08$ & $1.73-4.30$ & $4.01-4.61$ & $3.63-11.85$ \\
\hline$(\text { LREE/HREE })_{\mathrm{n}}$ & $0.02-0.87$ & $0.27-0.45$ & $0.97-1.94$ & $0.50-0.61$ & $2.07-3.39$ & $3.19-3.46$ & $4.43-8.40$ \\
\hline
\end{tabular}

\subsubsection{Slightly enriched peridotites (group 3)}

Clinopyroxene 1 in this group is characterised by $\mathrm{Mg \#}$ between 93 and 94 and low concentrations of $\mathrm{Al}_{2} \mathrm{O}_{3}, \mathrm{Cr}_{2} \mathrm{O}_{3}, \mathrm{Na}_{2} \mathrm{O}$, and $\mathrm{TiO}_{2}$ (Table 1). Similarly to Cpx1 described in Group 2, this clinopyroxene shows depletion in most incompatible LREE and low HFSE and LILE contents (Fig. 8C, D; Appendix 4). A second type of clinopyroxene (Cpx2) has slightly lower $\mathrm{Mg} \#$ and overall higher $\mathrm{Al}_{2} \mathrm{O}_{3}, \mathrm{Cr}_{2} \mathrm{O}_{3}, \mathrm{Na}_{2} \mathrm{O}$ and $\mathrm{TiO}_{2}$ (Table 1). Cpx2 is also distinguished by an enrichment in the most incompatible LREE, evidenced by a higher $(\mathrm{La} / \mathrm{Yb})_{n}$ ratio and strong negative $\mathrm{Nb}$ and $\mathrm{Ti}$ anomalies (Fig. 8C, D; Table 1). A third type of clinopyroxene ( $\mathrm{Cpx} 3$ ) displays even lower $\mathrm{Mg \#}$ and $\mathrm{Cr}_{2} \mathrm{O}_{3}$ contents but higher $\mathrm{Al}_{2} \mathrm{O}_{3}, \mathrm{Na}_{2} \mathrm{O}$, and $\mathrm{TiO}_{2}$ (Table 1). Cpx3 shows a slight enrichment in La and $\mathrm{Ce}$ and convex upward LREE distribution and no marked anomalies of HFSE and Ti (Fig. 8C, D; Table 1). Orthopyroxene in this group of samples has a $\mathrm{Mg \#}$ ranging between 90.2 and 91.8. The major element composition of the Group 3 orthopyroxene is $\mathrm{Al}_{2} \mathrm{O}_{3}=3.1-4.3$ wt\%, $\mathrm{Na}_{2} \mathrm{O}=0.09-0.14$ wt $\%$, and $\mathrm{TiO}_{2}=$ 0.07-0.13 wt\% (Appendix 4). Olivine from this group has lower $\mathrm{Mg \#}$ values compared to those obtained for Group 2 olivine, ranging from 89.7 to 91.3 , while $\mathrm{CaO}$ contents are between 0.01 and $0.09 \mathrm{wt} \%$ and $\mathrm{NiO}$ between 0.3 and 0.5 wt\% (Appendix 4).

\subsubsection{Strongly enriched peridotites (group 4)}

Three types of clinopyroxene are identified in this group based on their major and trace element composition, namely clinopyroxene 4 (Cpx4), clinopyroxene 5 (Cpx5) and Clinopyroxene 6 (Cpx6). Overall,
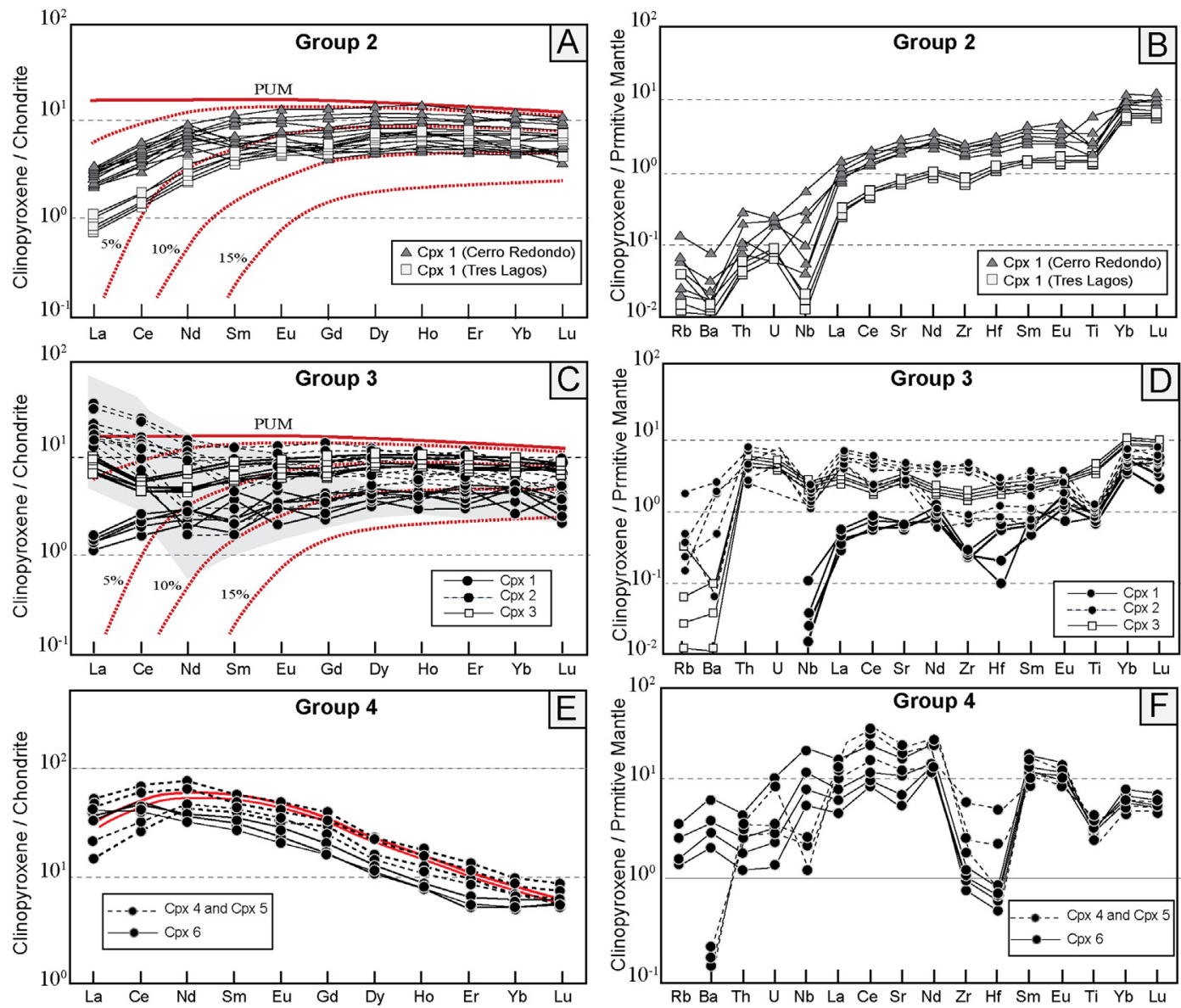

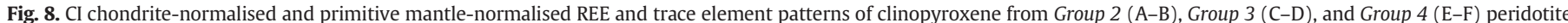

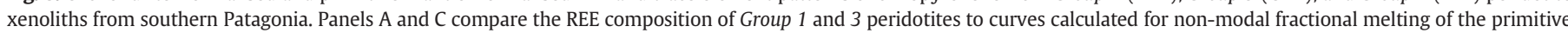

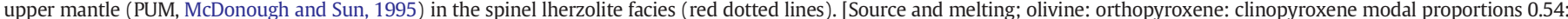

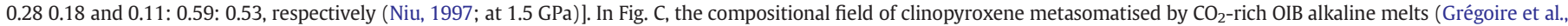


2017). Normalising values after McDonough and Sun (1995). 
they are characterised by a progressively lower $\mathrm{Mg \#}$ and $\mathrm{Cr}_{2} \mathrm{O}_{3}$ and increasing $\mathrm{Al}_{2} \mathrm{O}_{3}, \mathrm{TiO}_{2}$ and $\mathrm{NaO}$ (Table 1 ). $\mathrm{Cpx} 4$ and $\mathrm{Cpx} 5$ have a similar trace element composition (Appendix 4) and are characterised by a concave shaped REE pattern with $(\mathrm{La} / \mathrm{Yb})_{\mathrm{n}}$ ratio up to 5.5 and strong negative $\mathrm{Zr}$, Hf and Ti anomalies (Fig. 8D, E; Appendix 4). Clinopyroxene 6 (Cpx6) is the most abundant type in this group of peridotites and its $\mathrm{CI}$ chondrite-normalised REE pattern shows an overall negative slope with high LREE/HREE ratios and slightly softer negative anomalies of $\mathrm{Zr}$ and $\mathrm{Hf}$ compared to $\mathrm{Cpx} 4$ and $\mathrm{Cpx} 5$, and no Ti negative anomalies (Fig. 8D, E; Appendix 4). Orthopyroxene from Group 4 has the lowest Mg\# of all analysed samples between 88.9 and 89.5. The decrease in the $\mathrm{Mg \#}$ is accompanied by a decrease in $\mathrm{Al}_{2} \mathrm{O}_{3}(2.9-4.9 \mathrm{wt} \%)$, and an increase in $\mathrm{Na}_{2} \mathrm{O}(0.13-0.22 \mathrm{wt} \%)$ and $\mathrm{TiO}_{2}(0.12-0.2 \mathrm{wt} \%)$ (Table 1; Appendix 4). Olivine from Group 4 was distinguished into two different types based on the Mg\# and $\mathrm{CaO}$ content. Olivine 1 (Ol1) has the lowest $\mathrm{Mg}$ of all samples varying between 88.1 and 89.6 and a $\mathrm{CaO}$ content between 0.03 and $0.11 \mathrm{wt} \%$ whereas olivine 2 (Ol2) has higher $\mathrm{Mg \#}$ (90.8-92.1), which is accompanied by an increase in the $\mathrm{CaO}$ content of up to $0.2 \mathrm{wt} \%$ (Appendix 4).

\subsection{Mineral chemistry: metasomatic minerals}

Pargasitic amphibole is abundant in the Group 4 samples and is characterised by a low $\mathrm{TiO}_{2}(\sim 1.28 \mathrm{wt} \%)$, and high chlorine ( $0.38 \mathrm{wt}$ $\%$ ) and fluorine ( $0.17 \mathrm{wt} \%)$ content. Laurora et al. (2001) distinguished the pargasite from Gobernador Gregores samples into two groups based on their $\mathrm{TiO}_{2}$ concentration. The pargasite identified in this study falls between these two groups with respect to the $\mathrm{TiO}_{2}$ concentration although the pargasite from this study display higher content of $\mathrm{Ba}, \mathrm{Th}, \mathrm{Nb}, \mathrm{Ta}$, and $\mathrm{Zr}$ (Appendix 4). The major element composition of pargasite from Group 4 is reported in Appendix 4. Its trace element composition is characterised by LREE enrichment with respect to the $\operatorname{HREE}\left((\mathrm{La} / \mathrm{Yb})_{\mathrm{n}}=3.8-4.1\right)$, Ba is enriched with respect to Th and $\mathrm{U}$ $\left((\mathrm{Ba} / \mathrm{Th})_{\mathrm{n}}=5.3\right), \mathrm{Zr}$ and $\mathrm{Hf}$ are slightly depleted compared to the REE $\left((\mathrm{Zr} / \mathrm{Hf})_{\mathrm{n}}=1.64(\mathrm{Hf} / \mathrm{Sm})_{\mathrm{n}}=0.74\right)$ whereas $\mathrm{Nb}$ and Ta show strong positive anomalies ( $\sim 500$ times the $\mathrm{CI}$ chondrite contents) compared to the rest of the trace elements (Appendix 4).

Phlogopite identified in the Group 4 samples has a $\mathrm{Mg} \# \approx 92.56 \pm$ 0.04 , and $\mathrm{TiO}_{2}$ lower than 2 wt\%. Its REE content is lower than the pargasite by a factor of 2 orders of magnitude, sometimes close to or below the detection limit (10-60 ng.g ${ }^{-1}$, except for La, Ce and Eu. It is characterised by high concentrations of LILE as well as $\mathrm{Cl}$ and $\mathrm{F}$ (Appendix 4).

Carbonate and apatite from Group 3 and Group 4 peridotites were identified based on scanning electron microscopy-energy dispersive spectrometer (SEM-EDS). The SEM-EDS-semi-quantitative data obtained indicate that the carbonates are predominantly calcite with up to $\sim 6 \mathrm{wt} \% \mathrm{MgCO}_{3}$ and $\sim 0.5 \mathrm{wt} \% \mathrm{FeCO}_{3}$, similar to those identified in the same localities by Laurora et al. (2001). Apatite is a F-bearing apatite $(\mathrm{F} \approx 3 \mathrm{wt} \%, \mathrm{Cl} \approx 0.2 \mathrm{wt} \%$ ) found either as included grains within clinopyroxene or interstitial to the primary silicate assemblage.

\subsection{Petrography and major element composition of base-metal sulphides}

Base metals sulphides (with sizes varying from $\sim 1$ to $\sim 500 \mu \mathrm{m}$ ) were identified in all groups, except in Group 1 peridotites. The distribution of BMS in the peridotite xenoliths is heterogeneous, but generally, up to ten BMS grains were detected in each $9-\mathrm{cm}^{2}$ polished thick section. They occur either as: (i) inclusions within silicates (hereafter included; e.g., Fig. 9A-D), (2) along grain boundaries between silicates (hereafter interstitial; Fig. 9E, F), and (3) embedded within interstitial glass (hereafter glass-related; Fig. 9G, H).

Most BMS identified in the Group 2 lherzolites are glass-related and consist of single grains of millerite (NiS), or composite grains made up of pentlandite $(\mathrm{Fe}, \mathrm{Ni})_{9} \mathrm{~S}_{8} \pm \mathrm{Ni}$-rich mss $\left(\mathrm{Fe}_{1-\mathrm{x}}, \mathrm{Ni}_{1-\mathrm{x}} \mathrm{S}\right) \pm$ chalcopyrite $\left(\mathrm{CuFeS}_{2}\right)$ (chalcopyrite fraction $>20 \%$ volume). In addition, Fe-rich mss \pm pentlandite included within kink-banded olivine and Cpx1 were also identified in the Group 2 (Figs. 9G, H and 11; Appendix 5). The BMS from the Group 3 peridotites are Fe-rich mss located either included in olivine with undulating extinction, or more commonly interstitial to Cpx 2 and Cpx 3 often associated with carbonate or apatite
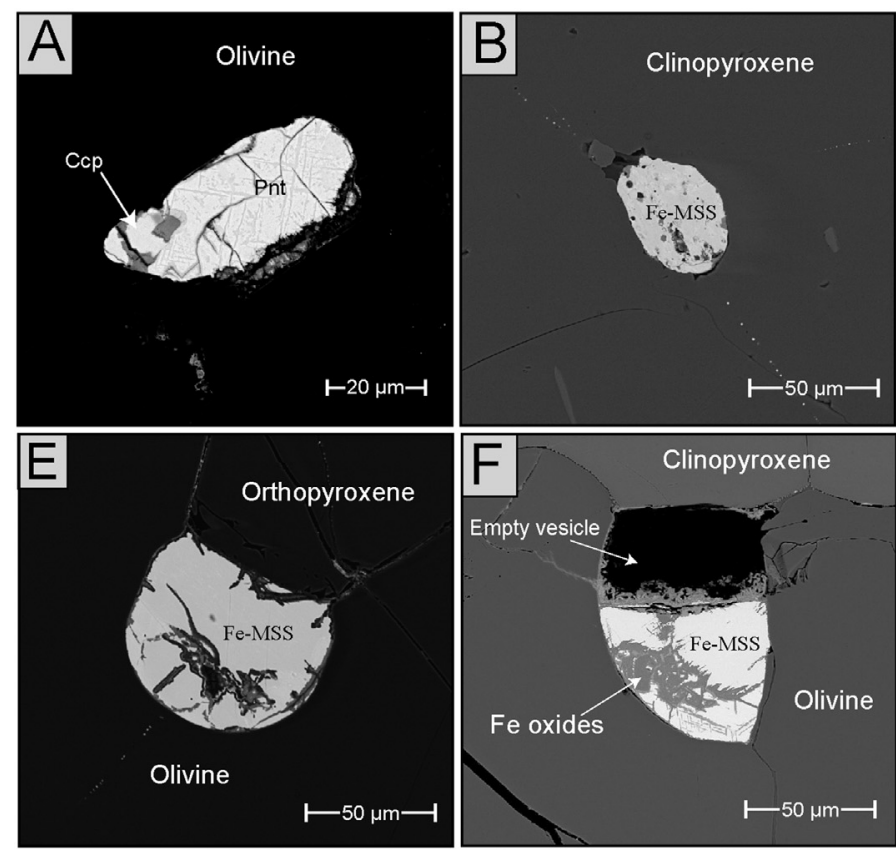
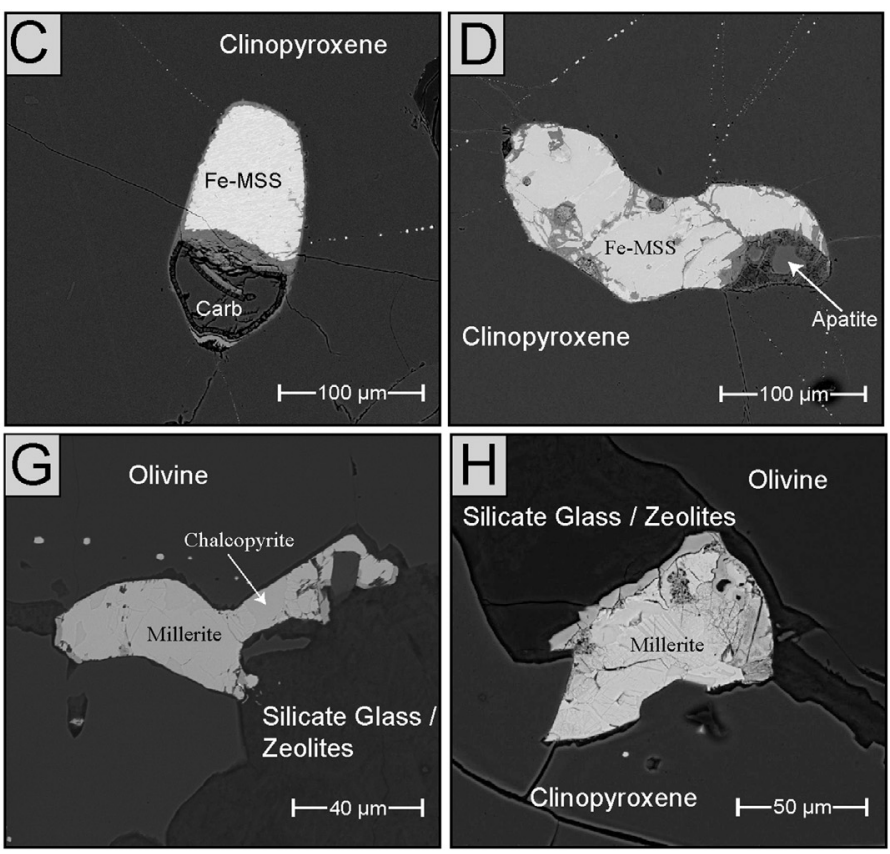

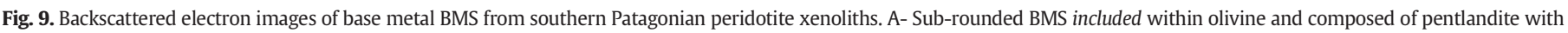

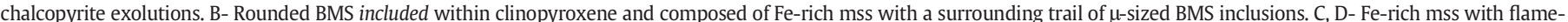

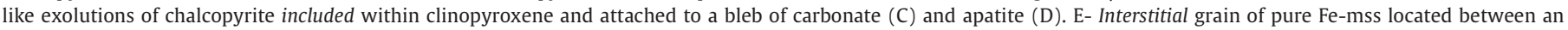

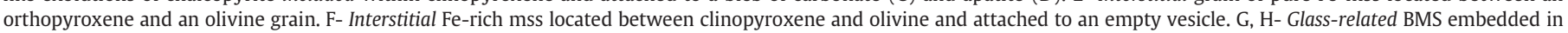
silicate glass composed of millerite with micro-textured chalcopyrite exolutions. 
blebs, and sometimes texturally located next to an empty vesicle (Figs. 9C, D, and 11; Appendix 5). In contrast, the BMS from the Group 4 peridotites are isolated grains of Fe-rich mss with or without pentlandite \pm pyrrhotite $\left(\mathrm{Fe}_{1-x} \mathrm{~S}\right) \pm$ cubanite $\left(\mathrm{CuFe}_{2} \mathrm{~S}_{3}\right)$ found included in, or interstitial to Cpx 4, Cpx 5 and Cpx 6 (Figs. 9G and 11; Appendix 5).

\subsection{In situ HSE and semi-metal abundances in base-metal sulphides}

HSE and chalcophile semi-metal (i.e., As, Se, Sb, Te, Bi, Pb) concentrations in BMS are reported in Appendix 5 and Fig. 11 shows the $\mathrm{CI}$ chondrite-normalised HSE patterns. Six distinct HSE patterns have been recognised for the BMS populations of the Patagonian mantle xenoliths (Table 2).

A subset of 17 out of 49 BMS exhibit the two types of $\mathrm{CI}$ chondritenormalised HSE patterns reported for the silicate-enclosed (i.e., residual; hereafter Type $1 A$ ) and interstitial (i.e., metasomatic; hereafter Type 2A) BMS described in peridotite xenoliths elsewhere (Alard et al., 2000, 2002; Aulbach et al., 2004; Griffin et al., 2002, 2004; Powell and O'Reilly, 2007; Saunders et al., 2015). Type 1A BMS exhibit nearly flat to smoothly negative slope from Os to Rh and pronounced negative slope from Pt to Re (Fig. 11A), which is reflected in (PPGE/ IPGE $)_{n}$ ratios between 0.03 and 0.21 . They have the highest Os-Ir-Ru but the lowest Au and Re concentrations and consist of Fe-rich mss included within primary olivine with deformation textures or within residual clinopyroxene (Cpx1). Type 2A BMS have the lowest total HSE concentrations but exhibit the highest Au contents (up to $12 \mu \mathrm{g} \cdot \mathrm{g}^{-1}$ ) (Fig. 11B). These BMS display CI chondrite-normalised HSE patterns characterised by a positive slope $\left((\mathrm{PPGE} / \mathrm{IPGE})_{\mathrm{n}}=1.91-14.04\right.$; Fig. 11B) and consists of isolated grains of Fe-rich mss or Fe-rich mss \pm pentlandite \pm chalcopyrite \pm cubanite. They occur as interstitial grains to Cpx2, and Cpx3 in Group 3 peridotites (samples TL-01, TL-03, GG-10, GG-13) as well as included or interstitial grains to Cpx4 and Cpx5 in the Group 4 peridotites (samples GG-01-A, GG-03, GG-17).

Two sub-types (Type $1 \mathrm{~B}$ and Type $2 \mathrm{~B}$ ) of the Type $1 \mathrm{~A}$ and Type $2 \mathrm{~A} \mathrm{CI}$ chondrite-normalised HSE patterns have been identified in BMS associated with metasomatic F-apatite and Mg-rich carbonate, and/or empty vesicles (Fig. 9C, D, and F). These BMS occur (i) predominantly as interstitial components associated with $\mathrm{Cpx} 3$ (Type $1 B$ ) and (ii) to a lesser extent as included grains within Cpx3 (Fig. 6C, D) of the Group 3 or included within Cpx6 of the Group 4 peridotites (Type 2B). The Type $1 B$ BMS have similar total HSE contents than the Type $1 \mathrm{~A}$, with a negative sloped CI chondrite-normalised HSE pattern. In contrast to the Type $1 A$, the Type $1 B$ BMS (Fe-rich mss) display a pronounced positive Pd anomaly $\left((\mathrm{Pd} / \mathrm{Pt})_{\mathrm{n}}=1.8-6.4\right.$; Fig. $\left.11 \mathrm{C}\right)$. This $(\mathrm{Pd} / \mathrm{Pt})_{\mathrm{n}}$ roughly increases with the concentration of Re (up to $6 \mu \mathrm{g} . \mathrm{g}^{-1}$ ) and the chalcophile semimetals (Fig. 11C, Appendix 5). On the other hand, the Type 2B BMS, also associated either with $\mathrm{Mg}$ carbonates, F-apatite blebs or empty vesicles (Fig. 9C, D, and F) exhibit similar to lower total HSE concentrations and distribution to the Type 2A. The Type 2B BMS (Fe-rich mss \pm pentlandite \pm pyrrhotite) also display a positive sloped $\mathrm{CI}$ chondritenormalised HSE pattern (Fig. 11D), but differentiates by its suprachondritic $(\mathrm{Os} / \mathrm{Ir})_{\mathrm{n}}$ ratio (1.3-5.3) as well as by its higher content in chalcophile semi-metals (Fig. 11D, Appendix 5).
The Type 3 BMS comprise isolated grains of millerite and Ni-rich mss \pm pentlandite \pm chalcopyrite exclusively found in glass-related sites in the Group 2 lherzolites (Fig. 9H). These BMS have total HSE concentrations intermediate between Type $1 B$ and Type $2 A$ and display flat $\mathrm{CI}$ chondrite-normalised HSE patterns (Type $3 A$ ), sometimes with a marked negative Pt anomaly and a slightly positive Pd anomaly (Type $3 B$ ) (Fig. 11E, F; Table 2). The semi-metals content in the Type $3 \mathrm{~A}$ and Type $3 B$ BMS are somehow intermediate to the BMS described above (Appendix 5).

Fig. 12 shows the co-variation between $(\mathrm{Os} / \mathrm{Ir})_{\mathrm{n}},(\mathrm{Pt} / \mathrm{Pd})_{\mathrm{n}}$ versus $\mathrm{S} / \mathrm{Se}$ and the Au content versus the S/Te ratios for each BMS type to evaluate the effect of semimetals on the HSE systematics. The Type $1 B$ and Type $2 B \mathrm{~S} / \mathrm{Se}$ ratios are restricted to a narrow range $(\sim 1000-6000)$ compared to the Type $1 A$ and Type $2 A$ that display a wider range of $S / S e$ ratios that extends towards one order of magnitude higher (Fig. 12A). In addition, the Type $2 B$ has the highest $(\mathrm{Os} / \mathrm{Ir})_{\mathrm{n}}$ ratios at the lowest $\mathrm{S} / \mathrm{Se}$ ratios (Fig. 12A). Fig. 12B shows that the Type $1 B$ and Type $2 B$ BMS have the highest $(\mathrm{Pd} / \mathrm{Pt})_{\mathrm{n}}$ ratios, which are roughly related to low $\mathrm{S} / \mathrm{Se}$ ratios. Fig. 12C, on the other hand, shows a negative correlation between the Au content and the S/Te ratios of the BMS. The Type $1 B$ and Type $2 B$ BMS have the lowest $\mathrm{S} / \mathrm{Te}$ and in the former, the Au content remains relatively low, whereas the latter shows the highest Au values.

\section{Discussion}

\subsection{Estimation of the degree of partial melting}

The suite of peridotite xenoliths analysed in this study range from strongly depleted (Group 1), slightly depleted (Group 2), slightly enriched (Group 3), to strongly enriched (Group 4) peridotites (Figs. 2, 4, 5). The depleted nature of the Group 1 and Group 2 peridotites is suggested by a combination of features including their lack or low modal percentage of clinopyroxene, high Mg\# of olivine, the absence of metasomatic phases, and the LREE depletion producing marked positive sloped $\mathrm{CI}$ chondrite-normalised REE patterns (Fig. 5). Figs. 5A, C, 8A, C show the estimated degree of partial melting that these rocks underwent, computed from their whole-rock and clinopyroxene REE distribution respectively for the non-modal fractional melting model of a PUM equilibrated in the spinel lherzolite facies. The results obtained using wholerock data indicate that the Group 1 peridotites experienced a minimum of $14-18 \%$ partial melting, whereas the Group 2 underwent $<14 \%$ partial melting (Fig. 5A, C). The estimated degree of partial melting is consistent with the low modal percentage of clinopyroxene. In contrast, the results obtained using Cpx1 from the Group 2 lherzolites indicate nonmodal fractional melting of up to $10 \%$ (Fig. 8A). The slight discrepancy observed between the partial melting estimations using the whole-rock and single mineral approach very likely reflect the effect of the interstitial glass in the whole-rock (e.g., Marchesi et al., 2017).

On the other hand, the presence of accessory amphibole, phlogopite, carbonate, and apatite in the Group 3 and Group 4 peridotites, indicates that metasomatism has overprinted any record of previous partial melting events. Therefore, partial melting estimations in these rock types can only be assessed by using the trace element distribution in primary clinopyroxene. Lherzolites of the Group 3 preserve Cpx1 characterised

Table 2

Summarised petrographic and compositional features of the different base-metal sulphides.

\begin{tabular}{|c|c|c|c|c|c|c|}
\hline & Type $1 A$ & Type $1 B$ & Type 2A & Type 2B & Type $3 A$ & Type 3B \\
\hline BMS phases & Fe-mss & Fe-mss & $\mathrm{Fe}-\mathrm{mss} \pm \mathrm{pnt} \pm \mathrm{Ccp} \pm \mathrm{Cb}^{\mathrm{a}}$ & Fe-mss \pm pnt \pm py & $\mathrm{Ni}-\mathrm{mss} \pm \mathrm{pnt} \pm \mathrm{ccp}$ & $\mathrm{Ni}-\mathrm{mss} \pm \mathrm{pnt} \pm \mathrm{ccp}$ \\
\hline Texture & Included & Interstitial $^{\mathrm{b}}$ & Included/Interstitial & Included/Interstitial $^{\mathrm{b}}$ & Glass-related & Glass-related \\
\hline Type of Cpx associated & 1 & 3 & $2,3,4,5$ & 3,6 & - & - \\
\hline$(\mathrm{PPGE} / \mathrm{IPGE})_{\mathrm{n}}$ & $0.03-0.21$ & $0.03-0.85$ & $1.91-14.04$ & $0.81-8.56$ & $0.68-1.11$ & $0.23-3.25$ \\
\hline$(\mathrm{Os} / \mathrm{Ir})_{\mathrm{n}}$ & $0.97-1.51$ & $0.48-1.63$ & $0.16-0.92$ & $1.34-5.34$ & $0.59-1.35$ & $0.30-2.04$ \\
\hline$(\mathrm{Pd} / \mathrm{Pt})_{\mathrm{n}}$ & $0.03-3.33$ & $1.81-6.42$ & $0.78-6.80$ & $0.74-34.28$ & $1.21-2.21$ & $0.59-1946.11$ \\
\hline
\end{tabular}

\footnotetext{
a pnt: pentlandite; ccp: Chalcopyrite; cb: Cubanite; py: Pyrrhotite; mill: Millerite.

b Attached to a carbonate or apatite bleb, or to an empty vesicle.
} 


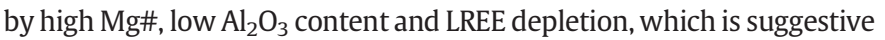
of a residual origin. Thus, a minimum of $12 \%$ degree of partial melting estimated was estimated from $\mathrm{Cpx} 1$ of the Group 3 by comparison with the PUM partial melting model (Fig. 8C).

In contrast, lherzolites and wehrlites from Group 4 contain only clinopyroxene (Cpx4, Cpx5, and Cpx6) displaying REE and trace element composition characterised by strong LREE enrichment relative the HREE; features clearly inconsistent with a residual origin (Fig. 6E, F) and therefore cannot be used for quantifying the degree of partial melting.

\subsection{Evidence of modal and cryptic volatile-rich metasomatism}

Several lines of evidence indicate strong cryptic and modal metasomatism in the Group 3 and Group 4 peridotites including: (1) an assemblage of volatile-rich minerals that include amphibole, phlogopite, apatite, and carbonate often associated with empty vesicles indicating degassing of a volatile-rich fluid/melt (Fig. 3G), (2) LREE enrichment in the whole-rock peridotites and clinopyroxene (Fig. 6C-F), and (3) identification of wehrlites forming after lherzolites.

Modal metasomatism recorded by the formation of apatite and carbonates commonly associated with empty vesicles suggest the infiltration of fluids and/or melts enriched in volatile components (e.g., C, H, F, S, P) and in the most incompatible trace elements (LREE, Sr, Th, U). In the Group 3 peridotites, the enrichment in the most incompatible trace elements (Fig. 5E, F) and the lower modal abundance of metasomatic minerals indicate that the rocks were modified by the infiltration of a metasomatic agent at very low fluid-melt/rock ratios. The $\mathrm{Cl}$ chondrite-normalised trace element patterns of these peridotites overlap with the pattern for fertile peridotite xenoliths from Montferrier in France (Fig. 5E), which were interpreted as metasomatised by melts enriched in a volatile component at relatively low fluid-melt/rock ratio (Alard et al., 2011). The $\mathrm{Cpx} 2$ from these peridotites display high $\mathrm{Mg \#}, \mathrm{Na}_{2} \mathrm{O}$ and $\mathrm{Cr}_{2} \mathrm{O}_{3}$ but low $\mathrm{TiO}_{2}$ and $\mathrm{Al}_{2} \mathrm{O}_{3}$ as well as LREE enrichment and(Fig. 6C, D), high LILE and negative $\mathrm{Nb}$ and Ta anomalies. These features are similar to those reported for mantle xenoliths from East Oman and Cameroon that have been metasomatised by $\mathrm{CO}_{2}$-rich and Na-bearing mafic silicate melts (Grégoire et al., 2009; Teitchou et al., 2011) as well as by alkali (silica-undersaturated and nepheline normative) basalts as described by Laurora et al. (2001) and Rivalenti et al. (2004) for Gobernador Gregores peridotite xenoliths. In fact, Gobernador Gregores Group 3 lherzolites (samples GG-05, GG-10, GG13) exhibit a stronger LREE/HREE fractionation and a strong negative $\mathrm{Ti}$ and moderately negative $\mathrm{Zr}$ and $\mathrm{Hf}$ anomalies, which is also compatible with metasomatism caused by $\mathrm{CO}_{2}$-rich and Na-bearing mafic silicate melts at relatively low melt/rock ratios. On the other hand, the Cpx3 from the Group 3 peridotites in the Tres Lagos has a greater $\mathrm{Al}_{2} \mathrm{O}_{3}$ and $\mathrm{TiO}_{2}$ content than $\mathrm{Cpx} 2$ and a REE pattern similar to that of the whole-rock, with lower LREE/HREE fractionation than the Cpx2, and without negative anomalies in $\mathrm{Ti}, \mathrm{Zr}$, and $\mathrm{Hf}$ (Fig. 6C, D). In contrast with the metasomatic imprint of $\mathrm{Cpx} 2, \mathrm{Cpx} 3$ features are consistent with a metasomatism produced by alkali silicate melts at relatively low melt/rock ratios.

Modal and cryptic metasomatism by carbonatite-like melts is better recorded in the Group 4 lherzolites and wehrlites from Gobernador Gregores. Infiltration of a carbonatite-like melt at high melt/rock ratios in these rocks is suggested by: (1) the higher modal abundance of metasomatic apatite and carbonates associated with amphibole and phlogopite, which were not identified in other metasomatised peridotites (Fig. 3), (2) the modal variation towards wehrlite (Figs. 2 and 4), and (3) the extremely high LREE/HREE fractionation and negative $\mathrm{Zr}, \mathrm{Hf}$, and $\mathrm{Ti}$ anomalies in whole-rock analyses (Fig. 5G, H; Coltorti et al., 1999). The imprint of evolving carbonatite melts is particularly well recorded in the different types of clinopyroxene identified in the Group 4 peridotites. Thus, $\mathrm{Cpx} 4$ is enriched in $\mathrm{Na}_{2} \mathrm{O}$ and characterised by a very high $\mathrm{Cr}_{2} \mathrm{O}_{3}$ and $\mathrm{Mg} \#$ and low $\mathrm{TiO}_{2}$ content, and exhibit a high LREE enrichment, $(\mathrm{La} / \mathrm{Yb})_{\mathrm{n}}, \quad(\mathrm{Zr} / \mathrm{Hf})_{\mathrm{n}}$ and low $(\mathrm{Ti} / \mathrm{Eu})_{\mathrm{n}}$, similar to clinopyroxene that typically crystallise from carbonatite-like melts (Fig. 6E, F) (e.g., Akizawa et al., 2017). In contrast, Cpx5 exhibits a similar minor and trace element distribution to Cpx4 (Fig. 6E, F; Appendix 2) but displays a higher $\mathrm{SiO}_{2}$ and $\mathrm{TiO}_{2}$ and lower $\mathrm{Na}_{2} \mathrm{O}$ content, which suggests the infiltration of a metasomatic melt with a stronger silicate component (Rivalenti et al., 2004). The Group 4 Cpx6 shows a marked $\mathrm{Fe}$ - Ti enrichment accompanied by an increase in $\mathrm{Al}_{2} \mathrm{O}_{3}$ at distinctly lower Mg\# than Cpx4 and Cpx5 (Appendix 2) without negative $\mathrm{Hf}$ and $\mathrm{Zr}$ anomalies. Thus, Cpx6 features are consistent with a crystallisation from late alkaline silicate melts percolating and metasomatising upper mantle peridotites at high melt/rock ratios (Rivalenti et al., 2004), also evidenced by cross-cutting relationships with former silicates (Fig. 3H, I).

In summary, we suggest that the Group 3 and Group 4 peridotites preserve the record of metasomatism caused by carbonatite-like melts that evolved towards $\mathrm{CO}_{2}$-rich mafic silicate melts and finally alkali silicate melts, although at different melt/rock ratios. During an early stage of infiltration at high melt/rock ratios, the carbonatite melt produced a strong modal metasomatism resulting in the crystallisation of apatite, carbonates and $\mathrm{Cpx} 4$ in the Group 4 peridotites. Progressive percolation and reaction of this carbonatite agent with the peridotite wallrock at decreasing melt volume gave rise to melts with stronger volatile and silicate component, resulting in $\mathrm{CO}_{2}$-rich mafic silicate melt that produced cryptic and modal metasomatism at low and high melt/rock ratios in the Group 3 and Group 4 peridotites, recorded in Cpx2 and Cpx5, respectively. Continued evolution of the melt after reaction with the peridotite wall-rock ended in the volatile-rich alkaline silicate melt that produced the in Cpx3 and Cpx6 in the peridotites of the Group 3 and Group 4 respectively. These observations are consistent with previous interpretations by Rivalenti et al. (2004) who showed that the metasomatic fingerprints of Gobernador Gregores mantle peridotites are the result of a single metasomatic melt evolving from $\mathrm{CO}_{2}$ rich nepheline-normative basalts towards silica saturation. Consistently, Hirose (1997), Dasgupta et al. (2006), and Mallik and Dasgupta (2013) experimentally demonstrated the evolution of carbonatite melts towards alkali basalts after percolation and reaction with a peridotite wall-rock whereas Zhang et al. (2017) showed the existence of natural $\mathrm{CO}_{2}$-rich silicate melts that continuously evolved to alkali basalts in the South China Sea.

\subsection{Nature of the interstitial glass}

As noted above, the Group 2 lherzolite samples from the Cerro Redondo contain glassy veinlets $(<60 \mu \mathrm{m})$ that infiltrate the interstices between pre-existing silicates. Electron microprobe analyses of these veinlets yield analytical totals $<88 \%$ and relatively high contents of $\mathrm{SiO}_{2}$ (46.7-51.7 wt\%), $\mathrm{MgO}$ (>28 wt\%) and $\mathrm{Al}_{2} \mathrm{O}_{3}$ (7.8-13.5 wt\%) (Appendix 4), which may reflect the presence of zeolites. Interstitial glass showing the same microstructural relationships and similar composition have been reported in other peridotite xenoliths equilibrated in the spinel facies (Demény et al., 2004; González-Jiménez et al., 2014; Miller et al., 2012; Neumann and Wulff-Pedersen, 1997; Scamberulli et al., 2009). The latter authors interpreted these textures as a result of (1) breakdown of hydrous minerals due to decompression melting, (2) host basalt infiltration, or (3) metasomatic melts that infiltrated the peridotite prior to the xenolith entrapment and ascent to surface. The glassy veinlets observed in the Group 2 peridotites could not be explained after breakdown or melting of hydrous phases because these are anhydrous lherzolites and the primitive mantle-normalised trace element patterns of the glassy veinlets are clearly distinct to those formed after the breakdown of hydrous minerals (Fig. 13). Disequilibrium reaction textures (Fig. 2C) in contact with clinopyroxene indicate that this late infiltrating silicate melt was very likely $\mathrm{SiO}_{2}$ under-saturated. Moreover, the PUM-normalised trace element patterns of the glass analysed here is very distinct to that of the host basalt 
and more alike to Na-alkali melts (Fig. 13). This is consistent with the observation that the interstitial glass analysed here still preserves a primary mineral assemblage -incompletely reacted olivine and partly corroded pyroxenes together with armalcolite $\left[\left(\mathrm{Mg}, \mathrm{Fe}^{2+}\right) \mathrm{Ti}_{2} \mathrm{O}_{5}\right]$, ilmenite, feldspar and apatite- that resulted from the evolution of silica undersaturated Na-alkali melts during percolation of the peridotite matrix (Grégoire et al., 2000; Ionov et al., 1999).

4.4. HSE mobility in the subcontinental lithospheric mantle beneath southern Patagonia

\subsubsection{Genesis of "unmodified" Type $1 A$ and Type $2 A$ base-metal sulphides}

Type 1A BMS consist of Fe-rich mss higher in Os, Ir, Ru, and $\mathrm{Rh}$ and lower in Pt, Pd, and Au, reflected in the CI chondrite-normalised HSE patterns with a marked negative slope $\left((\text { PPGE/IPGE })_{n}=0.24-0.68\right)$ (Fig. 11A). This signature, in addition to their occurrence as included minerals in olivine or residual Cpx1 indicates that these BMS are residues left after melt extraction of the upper mantle peridotite (Alard et al., 2000, 2002; Aulbach et al., 2004; Bockrath et al., 2004; Griffin et al., 2002) (Figs. 6, 11, 12; Appendix 4). Considering that partial melting estimations for these samples is of $\sim 10 \%$, preservation of these BMS is expected because in the mantle BMS are normally exhausted after $12-30 \%$ partial melting (Lorand and Grégoire, 2006), depending on sulfur abundance, pressure and oxygen fugacity (Jugo et al., 2010; Mavrogenes and O'Neill, 1999). This is also consistent with the experimental results that show the formation of IPGE-rich crystalline mss if the percentage of melting of the peridotite is below 10\% (Fonseca et al., 2012). The preservation of residual Type 1A sulphides (and Cpx1) in the Group 3 peridotites is also consistent with metasomatism at low melt/rock ratios that have not completely erased residual signatures of the rock-forming minerals. Fig. 10 shows that this type of Ferich mss crystallised at $\sim 1000^{\circ} \mathrm{C}$, consistent with the temperature estimated for the re-equilibrium of $\mathrm{Cpx} 1$ (Appendix 2).

In contrast, the Type $2 A$ BMS are rich in Pt, Pd, and Au relative to Os, $\mathrm{Ir}, \mathrm{Ru}$, and Rh ((PPGE/IPGE) $\mathrm{n}=2.1-17.1)$ (Fig. 11B; Appendix 4). They consist of isolated grains of Fe-rich mss or Fe-rich mss \pm pentlandite \pm cubanite included in or interstitial to olivine or secondary clinopyroxene (i.e., metasomatised $\mathrm{Cpx} 2$, and metasomatic $\mathrm{Cpx} 4$ and Cpx5). These BMS may represent blebs of immiscible Fe-Ni-Cu sulphide melt extracted by the incongruent melting of the BMS originally included in primary silicates and/or crystallised products by the $\mathrm{CO}_{2}$-rich mafic silicate melt (Harvey et al., 2010a). Later annealing or growth of cooling silicates could also mechanically include some of these Type $2 \mathrm{~A}$ BMS originally located in an interstitial position, thus explaining why this type of BMS are sometimes included within olivine grains (Griffin et al., 2002).

\subsubsection{Reworking of base-metal sulphides by $\mathrm{CO}_{2}$-phosphate-rich} metasomatic agents

The Type $1 B$ BMS CI chondrite-normalised HSE pattern resembles that of the Type $1 A$, whereas that of the Type $2 B$ resembles the Type $2 A$. However, the BMS Type $1 B$ and Type $2 B$ have a significantly higher semi-metal elements ( $\mathrm{As}, \mathrm{Se}, \mathrm{Sb}, \mathrm{Te}, \mathrm{Bi}, \mathrm{Pb}$ ) contents (Appendix 5). This overall increase in the semi-metal content of the BMS corresponds with the higher content of Os, Pd, Au, and Re (Fig. 11C, D). Type 1B BMS are Fe-rich mss found interstitial to $\mathrm{Cpx} 3$ (metasomatised by volatilerich alkaline silicate melt) in the Group 3 peridotites that were affected by metasomatism at low melt/rock ratios. We suggest that these were originally Type $1 \mathrm{~A}$ grains that were reworked in situ and therefore have their original composition modified by interaction with the infiltrating volatile-rich alkaline silicate melt. Such, reworking likely produced a remobilisation during melt-rock interaction, thus explaining why Type $1 B$ BMS occur only in an interstitial position. This modification also defined a slightly different $\mathrm{CI}$ chondrite-normalised HSE pattern characterised by a marked increase in Pd and Re relative to Pt and Au respectively, as well as an increase in the chalcophile semi-metals (Figs 12C, Appendix 5). Crystallisation temperatures of these Type $1 B$ BMS are similar to those of the Type $1 \mathrm{~A}\left(\sim 1000^{\circ} \mathrm{C}\right)$, also indirectly supporting a subsolidus modification of the Type $1 A$ to form the Type $1 B$ BMS.

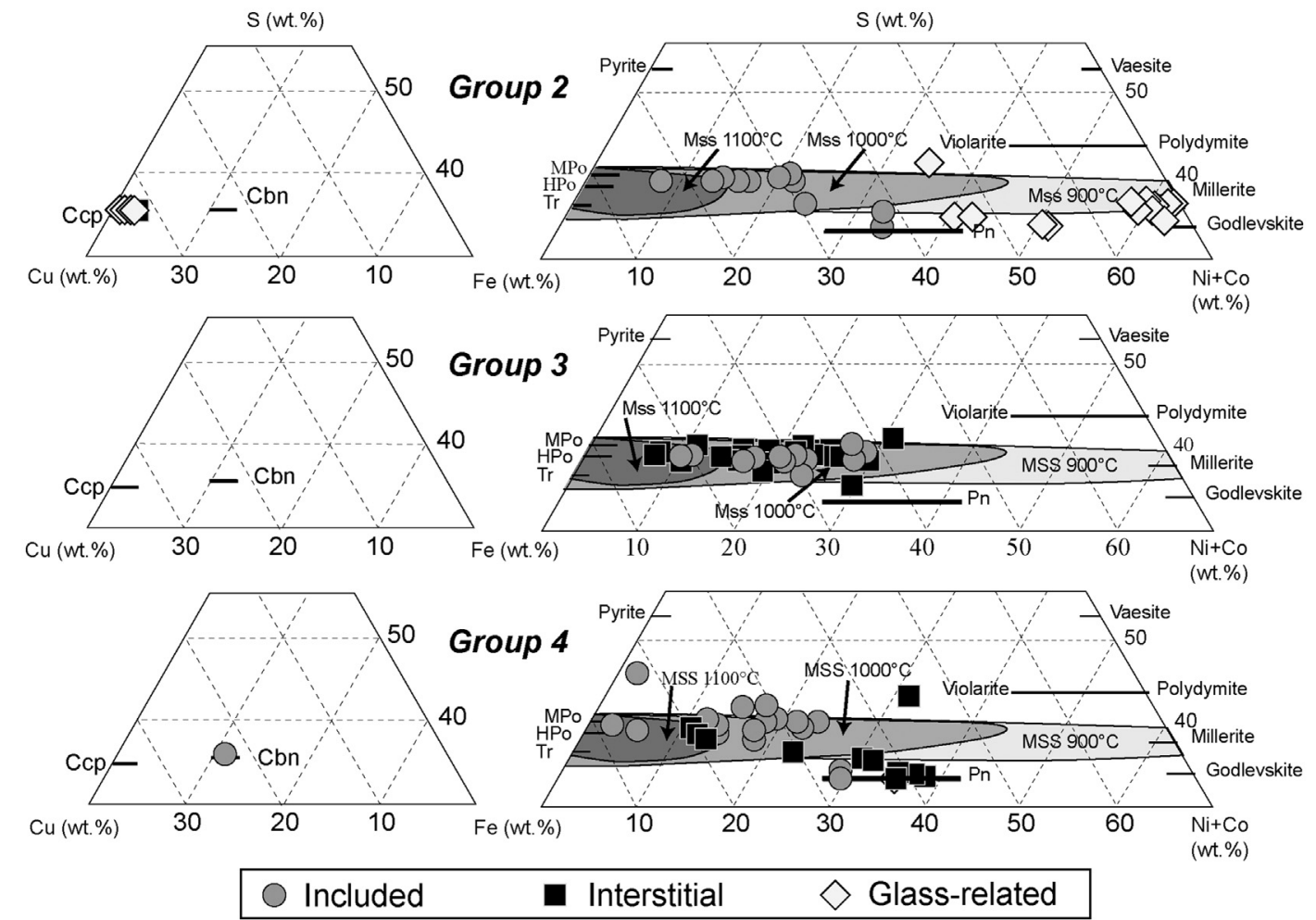

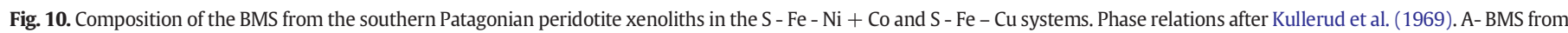
Group 2 samples. B- BMS from Group 3 samples. C- BMS from Group 4 samples. 



$\bigcirc$ Included $\square$ Interstitial $\diamond$ Glass-related $\longrightarrow$ Group $2-$ Group $3 \quad$ - - - - Group 4

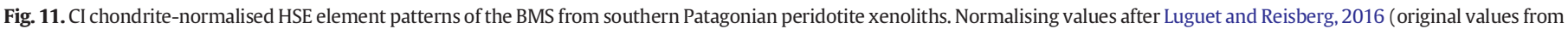
Horan et al. (2003) and Fischer-Gödde et al. (2010)).

In contrast, Type 2B BMS from Group 3 and Group 4 peridotites consist of Fe-rich mss \pm pentlandite \pm pyrrhotite that is commonly associated with metasomatic apatite, carbonate, or newly crystallised Cpx3 or Cpx6. Particularly, the Type 2B BMS have systematically suprachondritic $(\mathrm{Os} / \mathrm{Ir})_{\mathrm{n}}$ as well as a high $(\mathrm{Pd} / \mathrm{Pt})_{\mathrm{n}}$ ratio and Au content. The bleb-like textures and the contacts between the BMS and the apatite and carbonate (Fig. 9C, D) suggest that these BMS may represent molten globules of Type $2 A$ BMS removed as partially molten mattes along with bubbles of $\mathrm{CO}_{2}$ - and phosphate-rich melts owing their preferential wetting properties relative to silicate melts (Mungall, 2015). Alternatively, they could be the solid product of immiscible droplets formed by sulphide carbonate-phosphate once the Type 2A BMS were dissolved in the infiltrating melt enriched in sulfur, carbonate and phosphate (Hughes et al., 2017; O'Driscoll et al., 2018). In either case, the Cu-Ni fraction should have been removed during partial melting while the overall signature of HSE of the older Type 2A BMS was preserved. The latter highlights that $\mathrm{CO}_{2}$ - and P-rich melts are an effective way of transferring the absolute original HSE abundances of the mantle to the migrating magmas. Indeed, the suprachondritic $(\mathrm{Os} / \mathrm{Ir})_{\mathrm{n}}$ and high $(\mathrm{Pd} /$ $\mathrm{Pt})_{\mathrm{n}}$ ratios exhibited by the Type $1 B$ and Type $2 B$ BMS are symptomatic of this volatile-rich metasomatism. In addition, contrary to metasomatic BMS assemblages in mantle peridotites and pyroxenites (Delpech et al.,
2012; Saunders et al., 2016) that show elevated S/Se ratios, we found a positive correspondence between $\mathrm{Pd}$ and $\mathrm{Au}$, and the total content of semi-metals (Fig. 12) in the Type $1 B$ and Type $2 B$ BMS. The latter suggests that semi-metals might play a significant role either in mobilizing or fixing the most incompatible HSE (Helmy and Fonseca, 2017), adding complexity to the yet underexplored behaviour of the semi-metal elements in the mantle.

\subsubsection{Base-metal sulphide remobilisation by late infiltrating Na-rich} alkaline melts

The Type $3 A$ and Type $3 B$ BMS consist of millerite and Ni-rich mss ( \pm pentlandite \pm chalcopyrite) that are exclusively found embedded in the interstitial silica under-saturated Na-alkali metasomatic glass of the Group 2 peridotites. These BMS exhibit CI chondrite-normalised HSE patterns with a nearly flat shape (Type $3 A$ ), and variable negative Pt and slight positive Pd and Re anomalies (Type 3B). Near flat shapes of the CI chondrite-normalised HSE patterns in mantle Ni-Fe-Cu sulphides assemblages are typical of BMS derived from the direct crystallisation of sulphide melts segregated by liquid immiscibility from silicate melts (González-Jiménez et al., 2014; Lorand et al., 2008, 2010, 2013; Wang et al., 2009). Metal-sulphide equilibrium in the Ni-Fe-S system (Wood, 1987) indicates that the high-temperature 

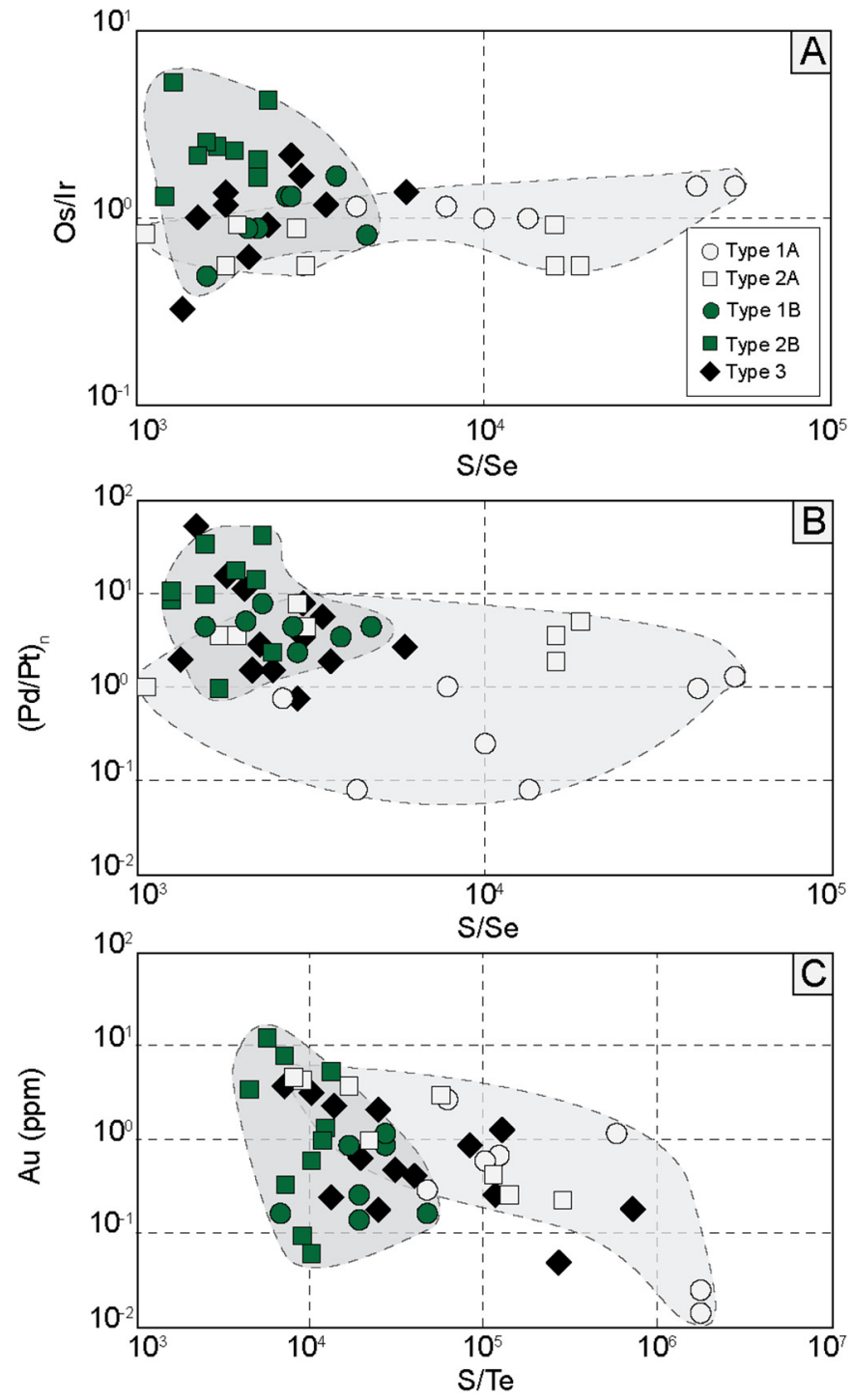

Fig. 12. Bivariate plots of the $(\mathrm{Os} / \mathrm{Ir})_{\mathrm{n}}$ and $(\mathrm{Pd} / \mathrm{Pt})_{\mathrm{n}}$ versus the $\mathrm{S} / \mathrm{Se}$ ratios of the different types of BMS identified in this study (A and B respectively). C-Correspondance between the Au content and the $\mathrm{S} / \mathrm{Te}$ ratios of the different types of BMS identified in this study.

polymorph of millerite $\alpha$-NiS is stable at temperatures between 1000 and $1200{ }^{\circ} \mathrm{C}$ and a low sulfur fugacity $\left(\log f S_{2}\right.$ from -0.5 to 1$)$ relevant for the formation of Na-alkali metasomatic glass. The early crystallisation of $\alpha$-NiS directly from melts can explain the presence of millerite crystals associated or not with other BMS (Fig. 9H; Appendix 4). Moreover, Ni-rich mss \pm pentlandite \pm chalcopyrite assemblages may also be interpreted as the product of subsolidus re-equilibrium of mss crystallised from immiscible Ni-Fe-Cu rich sulphide melts. Experimental data on the Fe-Ni-Cu system (Ballhaus et al., 2001; Craig and Kullerud, 1969; Fleet and Pan, 1994) shows that mss is the first phase that crystallised from a Fe-Ni-Cu sulphide melt once it was separated by liquid immiscibility from a mafic silicate melt. At $1000{ }^{\circ} \mathrm{C}$, this mss coexists with a $\mathrm{Cu}$-rich melt that may incorporate variable amounts of $\mathrm{Ni}$ (Ballhaus et al., 2001; Craig and Kullerud, 1969). As the temperature cools down to $T<600{ }^{\circ} \mathrm{C}$, the mss recrystallized to pentlandite giving rise to assemblages of pentlandite \pm chalcopyrite (Appendix 4). We suggest that the Type $3 A$ and Type $3 B$ BMS are quenched droplets of immiscible sulphide liquid that were transported by the infiltrating silica under-saturated Na-rich alkaline melt just before the eruption of the xenolith. These droplets could be either exsolved upon degassing and quenched due to rapid undercooling of the ascending xenolith. Alternatively, they could represent droplets of immiscible sulphide
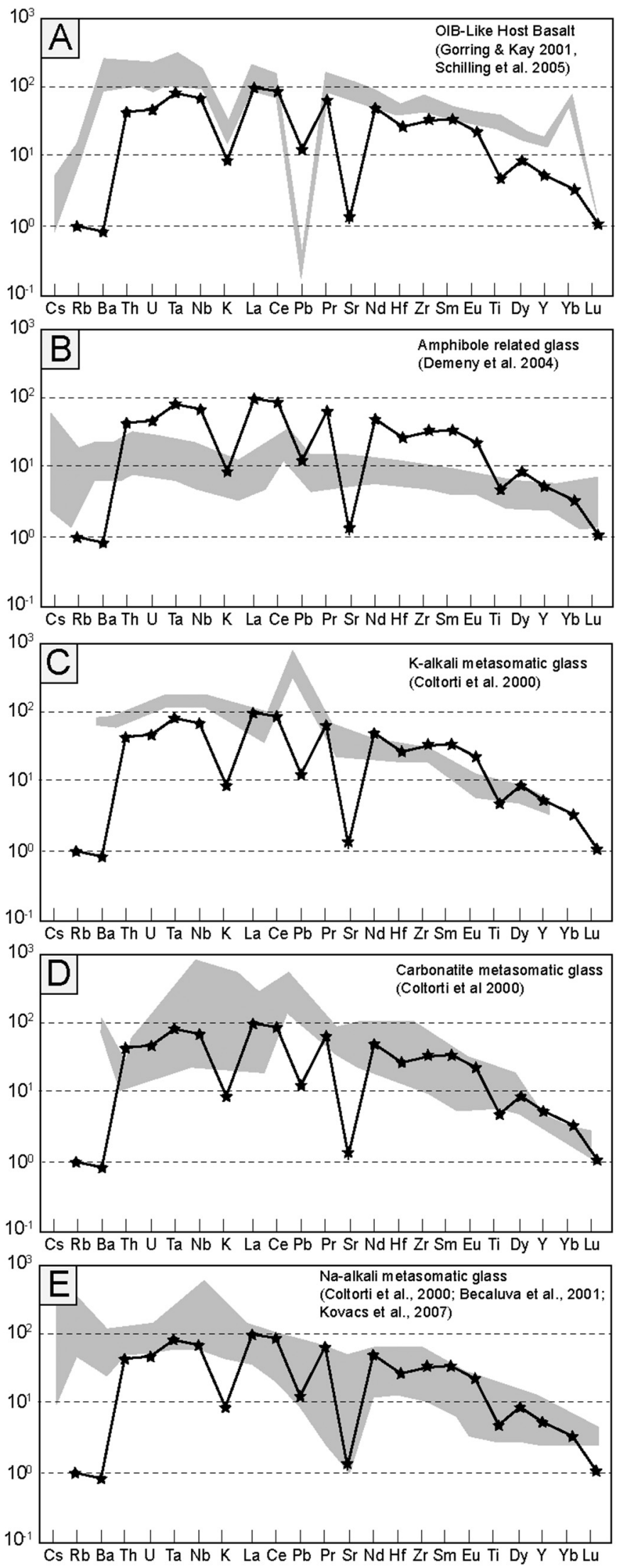

Fig. 13. CI chondrite-normalised trace element composition of the interstitial glass in Group 2 peridotites compared with glasses from mantle xenoliths formed after different possible origins. Normalising values after McDonough and Sun (1995). 


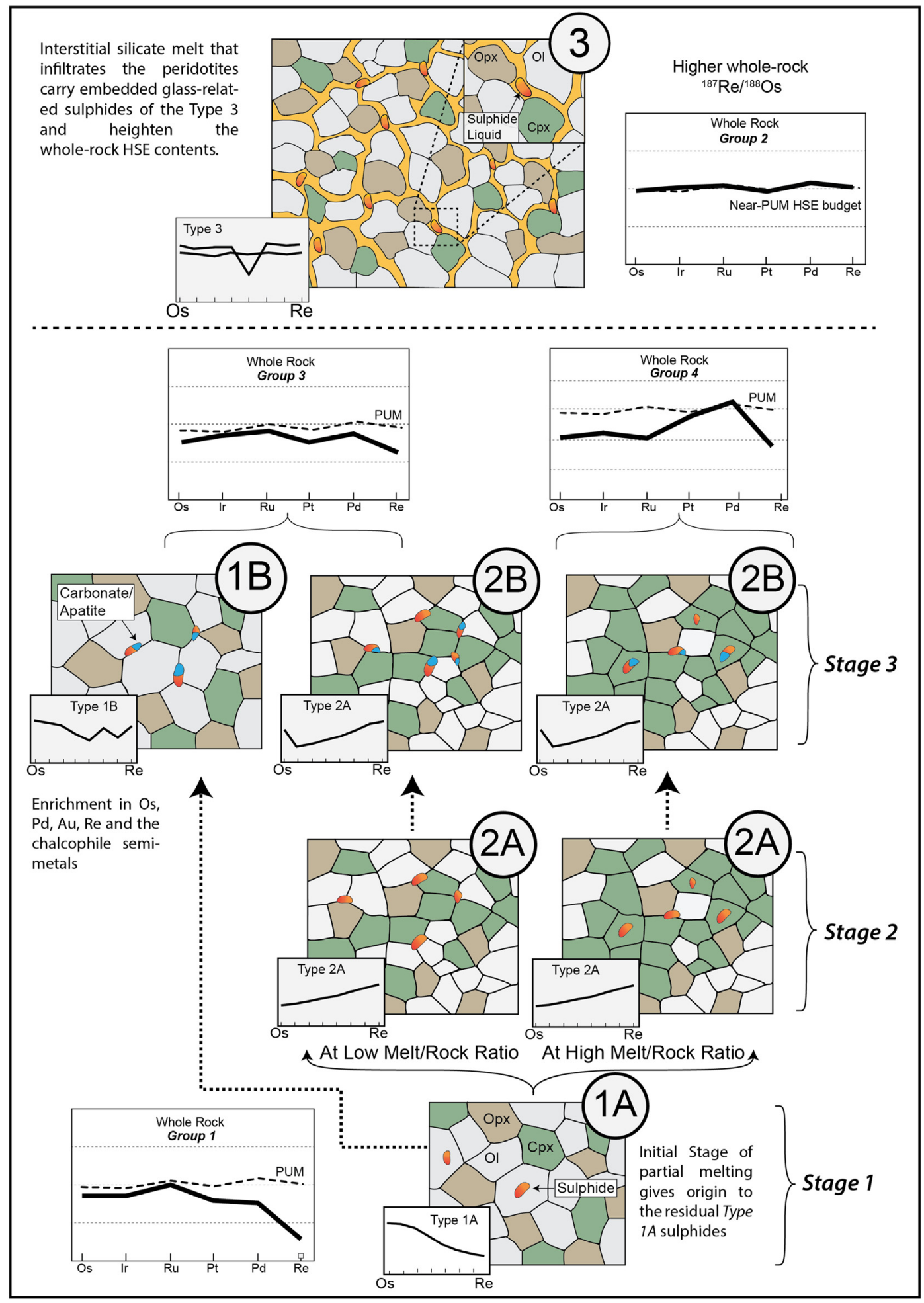

Fig. 14. Cartoon showing the likely sequence of events that occurred during the genesis of the different types of BMS defined in this study.

melt already segregated in from the infiltrating alkaline magma because of melt-rock reactions, thus explaining the common association of these types of BMS with empty vesicles. These empty vesicles could represent former vapour bubbles to which BMS were attached and transported in the upward-migrating melt against their natural tendency to settle due to gravity forces (Bockrath et al., 2004; Holzheid, 2010; Mungall, 2015).

The Type 3 BMS exhibit a slightly positive Pd anomaly as observed in the Type $1 B$ and Type $2 B$ as well as $\mathrm{Os} / \mathrm{Ir}$, $(\mathrm{Pt} / \mathrm{Pd})_{\mathrm{n}}$ ratios versus $\mathrm{S} / \mathrm{Se}$, and Au versus $\mathrm{S} / \mathrm{Te}$ that overlap that of the other BMS types (i.e., Type $1 \mathrm{~A}$,
Type 2A, Type $1 B$ and $2 B$; Fig. 12). The latter might indicate a possible heritage by removal of pre-existing BMS of the infiltrated peridotitic rock. The negative Pt anomaly could reflect the exsolution of Pt-rich nano-to-micron scale inclusions during subsolidus recrystallisation of the BMS assemblage, despite the fact that these have not been observed (e.g., Kogiso et al., 2008; Lorand et al., 2008; Luguet et al., 2007). The interpretation given above is consistent with the late nature of the late-infiltrating silica under-saturated Na-rich alkali melt and the variably higher ${ }^{187} \mathrm{Re} /{ }^{188}$ Os values at lower ${ }^{187} \mathrm{Os} /{ }^{188} \mathrm{Os}$ ratios of the Group 
2 peridotites, which indicates the recent addition of Re to the peridotites (see the following section).

4.4.4. Impact of melt depletion and metasomatism on the bulk-rock HSE and Re-Os systematics

The Group 1 peridotites exhibit CI chondrite-normalised HSE patterns characterised by an enrichment in Os, Ir, and Ru relative to Pt, $\mathrm{Pd}$, and Re (Fig. 6A), which is consistent with the strongly depleted nature of these peridotites (Fig. $5 \mathrm{~A}, \mathrm{~B}$ ). The oldest $T_{\mathrm{RD}} \approx T_{\mathrm{MA}}$ age obtained in this group of peridotites is $1.45 \mathrm{Ga}$ indicative that these peridotite xenoliths sampled volumes of ancient mantle beneath southern Patagonia, such as those previously identified in peridotite xenoliths from Tres Lagos (1.78 Ga; Schilling et al., 2017) and Pali Aike (2.5 Ga, Mundl et al., 2015). Given the degree of partial melting underwent by these rocks and their low $\mathrm{Al}_{2} \mathrm{O}_{3}$, the $T_{\mathrm{RD}}$ age of $0.34 \mathrm{Ga}$ obtained for the Tres Lagos sample in this group of peridotites could reflect a younger event of partial melting instead of later metasomatism, owing to the similarity of the $T_{\mathrm{RD}}$ and $T_{\mathrm{MA}}$ ages obtained for this group of samples (Rudnick and Walker, 2009).

The Group 2 lherzolites display the highest total HSE abundances, whereas their CI chondrite-normalised HSE patterns are near flat, PUM-like with overall Pt, Pd, and Re contents greater than in the Group 1, Group 3, and Group 4 peridotites (Fig. 6B). Such HSE enrichment can be explained as a result of the infiltration of the late silica undersaturated Na-rich alkali melt carrying Type $3 A$ and Type $3 B$ sulphides. A few of the Type 3 BMS have high concentrations of Re (up to $12 \mu \mathrm{g}^{-1}{ }^{-1}$ ) (Fig. 11E, F), and thus may have also added enough ${ }^{187} \mathrm{Re}$ to produce the decoupling between the high ${ }^{187} \mathrm{Re} /{ }^{188} \mathrm{Os}$ and low ${ }^{187} \mathrm{Os} /{ }^{188}$ Os that is observed for these group of samples (Fig. 7B), explaining the significant differences between the calculated $T_{\mathrm{RD}}$ and $T_{\mathrm{MA}}$ ages (Appendix 3 ). Therefore, the $T_{\mathrm{RD}}$ ages of the Group 2 peridotites (1.13-1.23 Ga for Cerro Redondo samples; Fig. 7D; Appendix 3) very likely reflect a minimum age of melt depletion owing the possible ingrowth of ${ }^{187} \mathrm{Os}$ by decay of ${ }^{187} \mathrm{Re}$ from the glass-related BMS of the Type $3 A$ and Type $3 B$, consistently with their estimated low degrees of partial melting ( $10 \%)$.

The slightly enriched peridotites (Group 3) display convex upwards shaped CI chondrite-normalised HSE patterns with depletion in Pt and $\mathrm{Re}$ and $(\mathrm{Pd} / \mathrm{Pt})_{\mathrm{n}}$ between 1.01 and 1.4. These rocks have a large discrepancy between the $T_{\mathrm{RD}}$ and $T_{\mathrm{MA}}$ ages in the youngest population (offset = 0.1-0.9 Ga; Appendix 3) indicating the post-melting metasomatic addition of ${ }^{187} \mathrm{Re}$, likely along with Pd, thus explaining the higher $\mathrm{CI}$ chondrite normalised values of Pd relative to the more compatible Pt. Such ${ }^{187} \mathrm{Re}$ addition could also explain the higher ${ }^{187} \mathrm{Os} /{ }^{188} \mathrm{Os}$ ratios obtained for the samples with low $\mathrm{Al}_{2} \mathrm{O}_{3}$ content (Fig. 7A). This is consistent with the preservation of a mixture of different generations of BMS including residual Type $1 \mathrm{~A}$ and metasomatic/metasomatised Type $1 \mathrm{~B}$, Type $2 A$, and Type $2 B$ related to the effect of metasomatism at low melt/rock ratios. Therefore, $T_{\mathrm{RD}}$ ages of the Group 3 peridotites (0.13-0.9 Ga; Fig. 7D; Appendix 3) likely reflects the mixture of the different generations of BMS added at different stages (different timing) of metasomatic modification such as Type $1 B$ and Type $2 B$ (with greater Re content) BMS (Fig. 7B) and later little ${ }^{187}$ Os ingrowth (Fig. 7C).

The strongly enriched peridotites (Group 4) from Gobernador Gregores display two types of CI chondrite-normalised HSE patterns. The subset of lherzolites GG-02, GG-07, and GG-14 that experienced mostly $\mathrm{CO}_{2}$-rich mafic silicate melt metasomatism exhibits convex upward shaped patterns and strong depletion in Os, Pt, Pd and Re. In contrast, the most metasomatised lherzolites (samples GG-03, GG-01A, GG-17) and wehrlite (sample GG-01-B) display CI chondritenormalised HSE patterns characterised by stronger enrichment in the PPGE relative to the IPGE (Fig. 6D; Appendix 3). This subset of highly metasomatised rocks contain predominantly Type $2 A$ and Type $2 B$ BMS formed by volatile-rich alkaline silicate melts and sulphide carbonatephosphate immiscibility characterised by higher PPGE contents and Re for the Type $2 B$ BMS, which explains the existence of meaningless $T_{\mathrm{RD}}$ (e.g., -7.94 and $-14.05 \mathrm{Ga}$ ) $T_{\mathrm{MA}}$ (e.g., $38.02 \mathrm{Ga}$ ) values (Appendix 3). Thus, the similar HSE distribution obtained by the whole-rock and individual BMS grains attest the key role of the latter in controlling the budget of metals in these peridotites. Moreover, it highlights that the HSE distribution is the result of the extensive infiltration of volatile-rich alkaline silicate melts, which have interacted with a pre-existing depleted mantle.

\subsubsection{Mobility of HSE and chalcophile semi-metals in the SCLM beneath} southern Patagonia

Fig. 14 summarises the sequence of events that have affected the HSE composition of the BMS and their peridotitic host rocks. Partial melting produced a depleted SCLM with: (1) almost no BMS grains with a high content of IPGE in the whole-rock (up to 18\% partial melting; Group 1), or (2) a slightly depleted mantle with surviving residual Type $1 \mathrm{~A}$ BMS included within silicates (up to $10 \%$ partial melting; Group 2 and Group 3) (Stage 1; Fig. 14). In the Group 3 peridotites, this was followed by metasomatism at low melt/rock ratios. Interaction of these rocks with $\mathrm{CO}_{2}$-rich mafic silicate melts led to the formation of metasomatic Type 2A BMS along with newly formed clinopyroxene (Cpx2) (Stage 2; Fig. 14). The later evolution of the melt towards volatile-rich alkali silicate melts produced a secondary modification of early BMS grains (Type $1 A$ and Type $2 A$ ), giving rise to the $\mathrm{Os}, \mathrm{Pd}, \mathrm{Re}$ and chalcophile semi-metals rich Type $1 B$ and Type $2 B$ BMS (Stage 3; Fig. 14). Thus, the resulting whole-rock $\mathrm{CI}$ chondrite-normalised HSE pattern of the Group 3 peridotites reflects a mixture of the different BMS-forming processes described above. In the Group 4 peridotites, the melt depletion event was followed by metasomatism operating at high melt/rock ratios. After such high degree of metasomatic modification by carbonatite to $\mathrm{CO}_{2}$-rich mafic silicate melts, the residual signatures of the Type $1 \mathrm{~A}$ BMS were erased and the metasomatic Type $2 \mathrm{~A}$ BMS were formed along with newly formed clinopyroxene (Cpx4 and Cpx5) (Stage 2; Fig. 14). Evolution of the melt towards volatile-rich alkali silicate melts and interaction with the peridotite produced a secondary modification of earlier generations of BMS (Type $2 A$ ) forming the Type $2 B$ BMS enriched in Os, Pd, Re and chalcophile semi-metals (Stage 3; Fig. 14). The metasomatic imprint recorded in Group 4 peridotites is particularly evident in the metasomatised lherzolites and wehrlite (samples GG-03, GG-01-A, GG-01-B, and GG-17), which equilibrated extensively with the percolating melt. This resulted in PPGE rich CI chondrite-normalised HSE patterns (resemblance to the melt) and highly radiogenic ${ }^{187} \mathrm{Os} /{ }^{188}$ Os compositions. Finally, the Group 2 lherzolites were percolated by silica under-saturated Na-alkali melts carrying immiscible $\mathrm{Ni}-\mathrm{Cu}$ rich sulphide liquids of the Type $3 \mathrm{~A}$ and Type $3 B$ which resulted in a strong refertilisation at the whole-rock scale as well as an addition of ${ }^{187}$ Re which resulted in a high HSE content and large difference between the $T_{\mathrm{RD}}$ and $T_{\mathrm{MA}}$ values.

\section{Conclusions and implications for metallogeny}

The peridotite xenoliths from southern Patagonia record a multistage history of depletion and subsequent metasomatism by carbonatite melts that evolved towards volatile and silica-rich compositions after reaction with the peridotite wall rock at variable melt/rock ratios. The volatile-rich alkaline silicate melts are agents that potentially may cause precipitation of BMS enriched in Os, Pd, Au, and Re, acting as an effective agent to remobilise and transport these HSE in the mantle. On the other hand, the infiltration of silica under-saturated Na-alkali melts (now the interstitial glass) carrying HSE-rich Ni-Cu immiscible sulphide droplets through the Group 2 lherzolites confirm previous experimental results (Ballhaus et al., 2001; Bockrath et al., 2004), highlighting the ability of silicate melts to transport immiscible $\mathrm{Ni}-\mathrm{Cu}$ rich sulphide melts enriched in HSE. This observation suggests that even at reducing conditions, the transport of BMS (and HSE $+\mathrm{Ni}+\mathrm{Cu}$ ) melts entrained in silicate melts can account as an important process in either (1) the refertilization in HSE of the SCLM, or (2) the 
scavenging of BMS from the SCLM by ascending melts as for Ni-Cu + PGE magmatic ore deposits (Griffin et al., 2013). Interestingly, the total whole-rock HSE contents of the Group 2 peridotites is the highest of all the studied samples indicating that in this case, the transport of immiscible sulphide melts promoted the HSE enrichment of a selected domain of the SCLM. The results of this study indicate that although further studies and experimental data are needed, $\mathrm{CO}_{2}$ and other volatile-rich melts may be important in the redistribution of HSE in the SCLM and may play an unforeseen role in metallogeny. In addition, we suggest that Na-rich alkaline silicate melts can capture sulphide melts from the SCLM, transport them as entrained droplets and eventually dissolve them into the silicate melt if favourable conditions (i.e., higher sulfur solubility) are reached, resulting in an effective mechanism to produce metal enrichment of mantle-derived magmas.

\section{Acknowledgements}

We acknowledge Andrew Kerr, Brian O'Driscoll and an anonymous reviewer for comments that significantly improved the first version of this manuscript. This research has been supported by a PhD scholarship from CONICYT (\#21170857) to Santiago Tassara and a France-Chile exchange project ECOS-CONICYT CU1501 to JMGJ and MG. Additional funding was provided by Millennium Science Initiative through the Millennium Nucleus for Metal Tracing along Subduction Grant NC130065, the FONDAP project 15090013 "Centro de Excelencia en Geotermia de Los Andes, CEGA" and DID-UACh project \#S-2015-52. Financial support for the in-situ analysis of HSE in base-metal sulphides was provided by the Ramón y Cajal Fellowship RYC-2015-17596 and the project CGL2014-55949-R granted by the Spanish "Ministerio de Economía y Competitividad" to JMGJ. Financial support for the Electron Microprobe and the LA-ICPMS analysis performed in Toulouse was provided by CNRS funding to MG. Financial support for LA-ICPMS analysis performed at the University of Chile was provided the CONICYTFondequip instrumentation grant EQM120098. We also thank X. Llovet (serveis Científico-Tècnics of the University of Barcelona), M. Leisen and R. Romero (Department of Geology, University of Chile) for their assistance during EPMA and LA-ICP-MS analyses respectively.

\section{Appendix A. Supplementary data}

Supplementary data to this article can be found online at https://doi. org/10.1016/j.lithos.2018.06.022.

\section{References}

Akizawa, N., Miyake, A., Ishikawa, A., Tamura, A., Terada, Y., Uesigi, K., Takeuchi, A., Arai, S. Tanaka, C., Igami, Y., Suzuki, K., Kogiso, T., 2017. Metasomatic PGE mobilization by carbonatitic melt in the mantle: evidence from sub- $\mu \mathrm{m}-\mathrm{scale}$ sulphidecarbonaceous glass inclusions in Tahitian harzburgite xenolith. Chem. Geol. 475 87-104.

Alard, O., Griffin, W.L., Lorand, J.-P., Jackson, S.E., O'Reilly, S.Y., 2000. Non-chondritic distribution of the highly siderophile elements in mantle sulphides. Nature 407, 891-894

Alard, O., Griffin, W.L., Pearson, N.J., O'Reilly, S.Y., 2002. New insights into the Re-Os systematics of sub-continental lithospheric mantle from in situ analysis of sulphides. Earth Planet. Sci. Lett. 203, 651-663.

Alard, O., Luguet, A., Pearson, N.J., Griffin, W.L., Lorand, J.-P., Gannoun, A., Burton, K.W. O'Reilly, S.Y., 2005. In situ Os isotopes in abyssal peridotites bridge the isotopic gap between MORBs and their source mantle. Nature 436, 1005-1008.

Alard, O., Lorand, J.-P., Resiberg, L., Bodinier, J.-L., Dautria, J.-M., O'Reilly, S.Y., 2011. Volatile-rich metasomatism in Montferrier xenoliths (Southern France): implications for the abundances of chalcophile and siderophile elements in the subcontinental mantle. J. Petrol. 52, 2009-2045.

Aliani, P., Ntaflos, T., Bjerg, E., 2009. Origin of melt pockets in mantle xenoliths from southern Patagonia, Argentina. J. S. Am. Earth Sci. 28, 419-428.

Aulbach, S., Griffin, W.L., O'Reilly, S.Y., McCandless, T.E., 2004. Genesis and evolution of the lithospheric mantle beneath the buffalo head Terrane, Alberta (Canada). Lithos 77, 413-451.

Baker, M.D., Stolper, E.M., 1994. Determining the composition of high pressure melts using diamond aggregates. Geochim. Cosmochim. Acta 58, 2811-2827.

Ballhaus, C., Tredoux, M., Späth, A., 2001. Phase relations in the Fe-Ni-Cu-PGE-S system at magmatic temperature and application to massive sulfide ores of the Sudbury igneous complex. J. Petrol. 42 (1991-1926).
Becker, H., Horan, M.F., Walker, R.J., Gao, S., Lorand, J.-P., Rudnick, R.L., 2006. Highly siderophile element compositions of the earth's primitive mantle. Geochim. Cosmochim. Acta 70, 4528-4550.

Begg, G.C., Hronsky, J.M.A., Arndt, N.T., Griffin, W.L., O'Reilly, S.Y., Hayward, N., 2010. Lithospheric, cratonic and geodynamic setting of Ni-Cu-PGE sulfide deposits. Econ. Geol. 105, 1057-1070.

Bockrath, C., Ballhaus, C., Holzheid, A., 2004. Fractionation of the platinum-group elements during mantle melting. Science 305, 1951-1953.

Coltorti, M., Bonadiman, C., Hinton, R.W., Siena, F., Upton, B.G.J., 1999. Carbonatite metasomatism of the oceanic upper mantle: evidence from clinopyroxenes and glasses in ultramafic xenoliths of Grande Comore, Indian Ocean. J. Petrol. 40, 303-320.

Craig, J.R., Kullerud, G., 1969. Phase relations in the Cu-Fe-Ni-S system and their application to magmatic ore deposits. Econ. Geol. Monogr. 4, 344-358.

Dasgupta, R., Hirschmann, M.M., Stalker, K., 2006. Immiscible transition from carbonaterich to silicate-rich melts in the $3 \mathrm{GPa}$ melting interval of eclogite $+\mathrm{CO}_{2}$ and genesis of silica-undersaturated ocean island lavas. J. Petrol. 47, 647-671.

Delpech, G., Lorand, J.-P., Grégoire, M., Cottin, J.-Y., O'Reilly, S.Y., 2012. In-situ geochemistry of sulphides in highly metasomatised mantle xenoliths from Kerguelen, southern India Ocean. Lithos 154, 296-314.

Demény, A., Wennemann, T.W., Hegner, E., Nagy, G., Milton, J.A., Embey-Isztin, A., Homonnay, Z., Dobosi, G., 2004. Trace element and C-O-Sr-Nd isotope evidence for subduction-related carbonate-silicate melts in mantle xenoliths (Pannonian Basin, Hungary). Lithos 75, 89-113.

D'Orazio, M., Agostini, S., Innocenti, F., Haller, M.J., Manetti, P., Mazzarini, F., 2001. Slab window-related magmatism from southernmost South america: the late Miocene volcanics from the Estancia Glen cross area (528S, Argentina-Chile). Lithos 57, 67-89.

Fischer-Gödde, M., Becker, H., Wombacher, F., 2010. Rhodium, gold and other highly siderophile element abundances in chondritic meteorites. Geochim. Cosmochim. Acta 74, 356-379.

Fleet, M.E., Pan, Y., 1994. Fractional crystallization of anhydrous sulfide liquid in the system Fe-Ni-Cu-S, with application to magmatic sulfide deposits. Geochim. Cosmochim. Acta 58, 3369-3377.

Fonseca, R.O.C., Laurenz, V., Mallmann, G., Luguet, A., Höne, N., Jochum, V., 2012. New constraints on the génesis and long-term stability of Os-rich alloys in the Earth's mantle. Geochim. Cosmochim. Acta 87, 227-242.

Forsythe, R.D., Nelson, E.P., Carr, M.J., Kaeding, M.E., Herve', M., Mpodozis, C., Soffia, J.M., Harambour, S., 1986. Pliocene near-trench magmatism in southern Chile: a possible manifestation of ridge collision. Geology 14, 23-27.

González-Jiménez, J.M., Villaseca, C., Griffin, W.L., O'Reilly, S.Y., Belousova, E., Ancochea, E., Pearson, N.J., 2014. Significance of ancient sulphides PGE and Re-Os signatures in the mantle beneath Calatrava, Central Spain. Contrib. Mineral. Petrol. 168, 1047.

Gorring, M.L., Kay, S.M., 2000. Carbonatite metasomatized peridotite xenoliths from southern Patagonia: implications for lithospheric processes and Neogene plateau magmatism. Contrib. Mineral. Petrol. 140, 55-72.

Gorring, M.L., Kay, S.M., 2001. Mantle processes and sources of Neogene slab window magmas from southern Patagonia, Argentina. J. Petrol. 42, 1067-1094.

Gorring, M.L., Kay, S.M., Zeitler, P.K., Ramos, V.A., Rubiolo, D., Fernandez, M., Panza, J.L., 1997. Neogene Patagonian plateau lavas: continental magmas associated with ridge collision at the Chile triple junction. Tectonics 16, 1-17.

Grégoire, M., Lorand, J.-P., Cottin, J.Y., Giret, A., Mattielli, N., Weis, D., 1997. Petrology of the Kerguelen mantle xenoliths: evidence of a refractory oceanic mantle percolated by basaltic melts beneath the Kerguelen Archipielago. Eur. J. Mineral. 9, 1085-1100.

Grégoire, M., Lorand, J.-P., O'Reilly, S.Y., Cottin, J.Y., 2000. Armalcolite-bearing, Ti-rich metasomatic assemblages in harzburgitic xenoliths from the Kerguelen Islands: implications for the oceanic mantle budget of high-field strength elements. Geochim. Cosmochim. Acta 64, 673-694.

Grégoire, M., Langlade, J.A., Delpech, G., Dantas, C., Ceuleneer, G., 2009. Nature and evolution of the lithospheric mantle beneath the passive margin of East Oman: evidence from mantle xenoliths sampled by Cenozoic alkaline lavas. Lithos 112, 203-2016.

Griffin, W.L., Spetius, Z.V., Pearson, N.J., O'Reilly, S.Y., 2002. In situ Re-Os analysis of sulphide inclusions in kimberlitic olivine: new constraints on depletion events in the Siberian lithospheric mantle. Geochem. Geophys. Geosyst. 3 (11).

Griffin, W.L., Graham, S., O'Reilly, S.Y., Pearson, N.J., 2004. Lithospheric evolution beneath the Kaapvaal Craton: Re-Os systematics of sulphides in mantle-derived peridotites. Chem. Geol. 208, 89-118.

Griffin, W.L., Begg, G.C., O'Reilly, S.Y., 2013. Continental-root control on the genesis of magmatic ore deposits. Nat. Geosci. 6, 905-910.

Harvey, J., Gannoun, A., Burton, K.W., Rogers, N.W., Schiano, P., Alard, O., 2010a. Selenium, tellurium, arsenic and antinomy contents of primary mantle sulphides. Can. Mineral. 40, 637-650.

Harvey, J., Gannoun, A., Burton, K.W., Schiano, P., Rogers, N.W., Alard, O., 2010b. Unravelling the effects of melt depletion and secondary infiltration on mantle Re-Os isotopes beneath the French massif central. Geochim. Cosmochim. Acta 74, 293-320.

Harvey, J., Yoshikawa, M., Hammond, S.J., Burton, K.W., 2012. Deciphering the trace element characteristicis in Kilbourne Hole peridotite xenoliths: melt-rock interaction and metasomatism beneath the Rio Grande rift, SW USA. J. Petrol. 53, 1709-1742.

Harvey, J., König, S., Luguet, A., 2015. The effects of melt depletion and metasomatism on highly siderophile and strongly chalchophile elements: S-Se-Te-Re-PGE systematics of peridotite xenoliths from Kilbourne Hole, New Mexico. Geochim. Cosmochim. Acta 166, 210-233.

Harvey, J., Warren, J.M., Shirey, S.B., 2016. Mantle sulphides and their role in Re-Os and Pb isotope geochronology. Rev. Mineral. Geochem. 81, 579-649.

Helmy, H.M., Fonseca, R.O.C., 2017. The behaviour of Pt, Pd, Cu and Ni in the Se-sulphide system between 1050 and $700^{\circ} \mathrm{C}$ and the role of Se in platinum-group elements fractionation in sulphide melts. Geochim. Cosmochim. Acta 216, 141-152. 
Hirose, K., 1997. Partial melt compositions of carbonated peridotites at $3 \mathrm{GPa}$ and role of $\mathrm{CO}_{2}$ in alkali-basalt magma generation. Geophys. Res. Lett. 24, 2837-2840.

Holzheid, A., 2010. Separation of sulfide melt droplets in sulfur saturated silicate liquids. Chem. Geol. 274, 127-135.

Horan, M.F., Walker, R.J., Morgan, J.W., Grossman, J.N., Rubin, A.E., 2003. Highly siderophile elements in chondrites. Chem. Geol. 196, 27-42.

Hronsky, J.M.A., Groves, D.I., Loucks, R.R., Begg, G.C., 2012. A unified model for gold mineralization in accretionary orogens and implications for regional-scale exploration targeting methods. Mineral. Deposita 47, 339-358.

Hughes, H.S.R., McDonald, I., Loocke, M., Butler, I.B., Upton, B.G.J., Faithfull, J.W., 2017. Paradoxical co-existing base metal sulphides in the mantle: the multi-event record preserved in Loch Roag peridotite xenoliths, North Atlantic Craton. Lithos 276, 103-121.

Ionov, D.A., Grégoire, M., Prikhod'ko, V.S., 1999. Feldspar - Ti-oxide metasomatism in off-cratonic continental and oceanic upper mantle. Earth Planet. Sci. Lett. 165, 37-44.

Ionov, D.A., Bodinier, J.-L., Mukasa, S.B., Zanetti, A., 2002. Mechanisms and sources of mantle metasomatism: major and trace element compositions of peridotite xenoliths from Spitsbergen in the context of numerical modelling. J. Petrol. 43, 2219-2259.

Jalowitzki, T., Gervasoni, F., Conceiçao, R.V., Orihasgi, Y., Bertotto, G.W., Sumino, H., Schilling, M., Nagao, K., Morata, D., Sylvester, P., 2017. Slab-derived components in the subcontinental lithospheric mantle beneath Chilean Patagonia: geochemistry and $\mathrm{Sr}-\mathrm{Nd}-\mathrm{Pb}$ isotopes of mantle xenoliths and host basalt. Lithos 292-293, 179-197.

Jugo, P.J., Wilke, M., Botcharnikov, R.E., 2010. Sulfur K-edge XANES analysis of natural and synthetic basaltic glasses: implications for $\mathrm{S}$ speciation and $\mathrm{S}$ content as function of oxygen fugacity. Geochim. Cosmochim. Acta 74, 5926-5938.

Kogiso, T., Suzuki, T., Suzuki, Y., Shinotsuka, K., Uesugi, K., Takeuchi, A., Suzuki, Y., 2008. Detecting micrometer-scale platinum-group minerals in mantle peridotite with microbeam synchrotron radiation X-ray fluorescence analysis. Geochem. Geophys. Geosyst. 9.

Kullerud, G., Yund, R.A., Moh, G., 1969. Phase relations in the Cu-Fe-S and Cu-Ni-S systems. In: Wilson, H.D.B. (Ed.), Magmatic Ore Deposits. vol. 4. Econ Geol Monogr, pp. 323-343.

Laurora, A., Mazzucchelli, M., Rivalenti, G., Vannucci, R., Zanetti, A., Barbieri, M.A., Cingolani, C., 2001. Metasomatism and melting in carbonated peridotite xenoliths from the mantle wedge: the Gobernador Gregores case (Southern Patagonia). J. Petrol. 42, 69-87.

Lorand, J.-P., Grégoire, M., 2006. Petrogenesis of base metal sulphide assemblages of some peridotites from the Kaapvaal craton (South Africa). Contrib. Mineral. Petrol. 151, 521-538.

Lorand, J.-P., Delpech, G., Grégoire, M., Moine, B., O'Reilly, S.Y., Cottin, J.Y., 2004. Platinumgroup elements and the multistage metasomatic history of Kerguelen lithospheric mantle (South Indian Ocean). Chem. Geol. 208, 195-215.

Lorand, J.-P., Luguet, A., Alard, O., 2008. Platinum-group elements: a new set of key tracers for the Earth's interior. Elements 4, 247-252.

Lorand, J.-P., Alard, O., Luguet, A., 2010. Platinum-group element micronuggets and refertilization process in the Lherz peridotite. Earth Planet. Sci. Lett. 289, 298-310.

Lorand, J.-P., Luguet, A., Alard, O., 2013. Platinum-group element systematics and petrogenetic processing of the continental upper mantle: a review. Lithos 164-167, 2-21.

Luguet, A., Reisberg, L., 2016. Highly siderophile element and 1870 s signatures in noncratonic basalt-hosted peridotite xenoliths: unravelling the origin and evolution of the post-Archean lithospheric mantle. Rev. Mineral. Geochem. 81, 305-367.

Luguet, A., Alard, O., Lorand, J.-P., Pearson, N., Ryan, C.G., O'Reily, S.Y., 2001. LAM-ICPMS unravels the highly siderophile element geochemistry of abyssal peridotites. Earth Planet. Sci. Lett. 189, 285-294.

Luguet, A., Lorand, J.-P., Seyler, M., 2003. Sulphide petrology and highly siderophile element geochemistry of abyssal peridotites: a coupled study in samples from the Kane fracture zone $\left(45^{\circ} \mathrm{W} 23^{\circ} 20 \mathrm{~N}\right.$, MARK area, Atlantic Ocean). Geochim. Cosmochim. Acta 67, 1553-1570.

Luguet, A., Lorand, J.-P., Alard, O., Cottin, J.Y., 2004. A multi-technique study of platinumgroup elements systematic in some Ligurian ophiolitic peridotites, Italy. Chem. Geol. 208, 175-194.

Luguet, A., Shirey, S.B., Lorand, J.-P., Horan, M.F., Carlson, R.W., 2007. Residual platinum-group minerals from highly depleted harzburgites of the Lherz massif (France) and their role in HSE fractionation of the mantle. Geochim. Cosmochim. Acta 71, 3082-3097.

Luguet, A., Behrens, M., Pearson, D.G., König, S., Herwartz, D., 2015. Significance of the whole rock Re-Os ages in cryptically and modally metasomatised cratonic peridotites: Constraints from HSE-Se-Te systematics. Geochim. Cosmochim. Acta 164, 441-463.

Mallik, A., Dasgupta, R., 2013. Reactive infiltration of MORB-eclogite-derived carbonated silicate melt into fertile peridotite at $3 \mathrm{GPa}$ and genesis of alkali magmas. J. Petrol. $54,2267-2300$.

Marchesi, C., Konc, Z., Garrido, C.J., Bosch, D., Hidas, K., Varas-Reus, M.I., Acosta-Vigil, A., 2017. Multi-stage evolution of the lithospheric mantle beneath the westernmost Mediterranean: geochemical constraints from peridotite xenoliths in the eastern Betic cordillera (SE Spain). Lithos 276, 75-89.

Mavrogenes, J., O'Neill, H.S.C., 1999. The relative effects of pressure, temperature and oxygen fugacity on the solubility of sulphide in mafic magmas. Geochim. Cosmochim. Acta 63, 1173-1180.

McDonough, W.F., Sun, S.-s, 1995. The composition of the earth. Chem. Geol. 120, 223-253.

McInnes, B.I.A., McBridge, J.S., Evans, N.J., Lambert, D.D., Andrew, A.S., 1999. Osmium isotope constrains on ore metal recycling in subduction zones. Science 286, 512-516.

Meisel, T., Walker, R.J., Irving, A.J., Lorand, J.-P., 2001. Osmium isotopic compositions of mantle xenoliths: a global perspective. Geochim. Comsochim. Acta 65, 135-137.

Miller, C., Zanetti, A., Thöni, M., Konzett, J., Klötzli, U., 2012. Mafic and silicat-rich glasses in mantle xenoliths from Wau-en-Namus, Libya: textural and geochemical evidence for peridotite-melt-rock reactions. Lithos 128, 11-26.

Moine, B., Grégoire, M., O'Reilly, S.Y., Delpech, G., Sheppard, S.M.F., Lorand, J.-P., Renac, C., Giret, A., Cottin, J.Y., 2004. Carbonatite melt in oceanic upper mantle beneath the Kerguelen Archipelago. Lithos 75, 239-252.
Mundl, A., Ntaflos, T., Ackerman, L., Bizimis, M., Bjerg, E.A., Hauzenberger, C.A., 2015 Mesoproterozoic and Paleoproterozoic subcontinental lithospheric mantle domains beneath southern Patagonia: isotopic evidence for its connection to Africa and Antarctica. Geology 43, 39-42.

Mungall, J.E., 2015. Physical controls of nucleation, growth and migration of vapor bubbles in partially molten cumulates. In: Charlier, B., Namur, O., Latypov, R., Tegner, C. (Eds.), Layered Intrusions. Springer Geology. Springer, Dordrecht.

Neumann, E.R., Wulff-Pedersen, E., 1997. The origin of highly silicic glass in mantle xenoliths from the Canary Islands. J. Petrol. 38, 1513-1539.

Niu, Y., 1997. Mantle melting and melt extraction processes beneath ocean ridges: evidence from abyssal peridotites. J. Petrol. 38, 1047-1074.

Ntaflos, T., Bjerg, E.A., Labudia, C.H., Kurat, G., 2007. Depleted lithosphere from the mantle wedge beneath Tres Lagos, southern Patagonia, Argentina. Lithos 94, 46-65.

O'Driscoll, B., González-Jiménez, J.M., 2016. Petrogenesis of the platinum-group minerals. Rev. Mineral. Geochem. 81, 489-578.

O'Driscoll, B., Walker, R.J., Clay, P.L., Day, J.M.D., Ash, R.D., Daly, J.S., 2018. Length-scales of chemical and isotopic heterogeneity in the mantle section of the Shetland Ophiolite complex, Scotland. Earth Planet. Sci. Lett. 488, 144-154.

Pankhurst, R.J., Riley, T.R., Fanning, C.M., Kelley, S.P., 2000. Episodic silicic volcanism in Patagonia and the Antarctic Peninsula: chronology of magmatism associated with the break-up of Gondwana. J. Petrol. 41, 605-625.

Pearson, D.G., Canil, D., Shirey, S.B., 2004. Mantle samples included in volcanic rocks: xenoliths and diamonds. In: Carlson, R.W. (Ed.), Treatise of Geochemistry. vol. 2. Elsevier, Amsterdam, pp. 171-275.

Powell, W., O'Reilly, S.Y., 2007. Metasomatism and sulphide mobility in the lithospheric mantle beneath eastern Australia: implications for mantle re-Os chronology. Lithos 94, 132-147.

Ramos, V.A., Aleman, A., 2000. Tectonic evolution of the Andes. Tectonic Evolution of South America. International Geological Congress, Rio de Janerio, pp. 635-685.

Rivalenti, G., Zanetti, A., Mazzucchelli, M., Vannucci, R., Cingolani, C., 2004. Equivocal carbonatite markers in the mantle xneoliths of the Patagonia backarc: the Gobernador Gregores case (Santa Cruz Province, Argentina). Contrib. Mineral. Petrol. 147, 647-670

Robinson, J.A.C., Wood, B.J., Blundy, J.D., 1998. The beginning of melting of fertile and depleted peridotite at 1.5 Gpa. Earth Planet. Sci. Lett. 155, 97-111.

Rudnick, R.L., Walker, R.J., 2009. Interpreting ages from Re-Os isotopes in peridotites Lithos 112S, 1083-1095.

Saunders, J.E., Pearson, N.J., O'Reilly, S.Y., Griffin, W.L., 2015. Sulphide metasomatism and the mobility of gold in the lithospheric mantle. Chem. Geol. 410, 149-161.

Saunders, J.E., Pearson, N.J., O'Reilly, S.Y., Griffin, W.L., 2016. Gold in the mantle: the role of pyroxenites. Lithos 244, 205-217.

Scamberulli, M., Vannucci, R., De Stefano, A., Preite-Martinez, M., Rivalenti, G., 2009. $\mathrm{CO}_{2}$ fluid and silicate glass as monitors of alkali basalt/peridotite interaction in the mantle wedge beneath Gobernador Gregores, Southern Patagonia. Lithos 107, 121-133.

Schilling, M.E., Carlson, R.W., Conceição, R.V., Dantas, C., Bertotto, G.W., Koester, E., 2008. Re-Os isotope constraints on subcontinental lithospheric mantle evolution of southern South America. Earth Planet. Sci. Lett. 268, 89-101.

Schilling, M.E., Carlson, R.W., Tassara, A., Conceição, R.V., Bertotto, G.W., Vásquez, M. Muñoz, D., Jalowitzki, T., Gervasoni, F., Morata, D., 2017. The origin of Patagonia revealed by Re-Os systematics of mantle xenoliths. Precambrian Res. 294, 15-32.

Stern, C.R., Frey, F.A., Futa, K., Zartman, R.E., Peng, Z., Kyser, T.K., 1990. Trace-element and Sr, Nd, $\mathrm{Pb}$, and $\mathrm{O}$ isotopic composition of Pliocene and quaternary alkali basalts of the Patagonia Plateau lavas of southernmost South America. Contrib. Mineral. Petrol. 104, 294-308.

Tassara, S., González-Jiménez, J.M., Reich, M., Schilling, M.E., Morata, D., Begg, G., Saunders, E., Griffin, W.L., O'Reilly, S.Y., Grégoire, M., Barra, F., Corgne, A., 2017. Plume-subduction interaction forms large auriferous provinces. Nat. Comms. 8, 843.

Teitchou, M.I., Grégoire, M., Temdjim, T., Ghogomu, R.T., Ngwa, C., Aka, F.T., 2011. Mineralogical and Geochemical Fingerprints of Mantle Metasomatism beneath Nyos Volcano (Cameroon Volcanic Line). Geological Geol Society Soc of America, pp. 193-210 Special paper 478 .

Van Acken, D., Luguet, A., Pearson, D.G., Nowell, G.M., Fonseca, R.O.C., Nagel, T.J., Schulz, T. 2017. Mesoarchean melting and Neoarchean to Paleoproterozoic metasomatism during the formation of the cratonic mantle keel beneath West Greenland. Geochim. Cosmochim. Acta 203, 37-53.

Walker, R.J., Prichard, H.M., Ishiwatari, A., Pimentel, M., 2002. The osmium isotopic composition of convecting upper mantle deduced from ophiolites chromites. Geochim. Cosmochim. Acta 66, 329-345.

Wang, J., Hattori, K.H., Kilian, R., Stern, C.R., 2007. Metasomatism of sub-arc mantle peridotites below southernmost South America: reduction of fO2 by slab-melt. Contrib. Mineral. Petrol. 153, 607-624.

Wang, J., Hattori, K.H., Li, J., Stern, C.R., 2008. Oxidation state of Paleozoic subcontinental lithospheric mantle below the Pali Aike volcanic field in southernmost Patagonia. Lithos 105, 98-110.

Wang, K.L., O'Reilly, S.Y., Griffin, W.L., Pearson, N.J., Zhang, M., 2009. Sulphides in mantle peridotites from Penghu Island, Taiwan: melt percolation, PGE fractionation, and lithospheric evolution of South China bloc. Geochim. Cosmochim. Acta 73, 4531-4557.

Widom, E., Kepezhinkas, P., Defant, M., 2003. The nature of metasomatism in the sub-arc mantle wedge: evidence from Re-Os isotopes in Kamchatka peridotite xenoliths. Chem. Geol. 196, 283-306.

Wilshire, H.G., Shervais, J.W., 1975. Al-augite and Cr-diopside ultramafic xenoliths in basaltic rocks from western United States. Phys. Chem. Earth 9, 257-272.

Wood, S.A., 1987. Thermodynamic calculations of the volatility of the platinum group elements (PGE): the PGE content of fluids at magmatic temperatures. Geochim. Cosmochim. Acta 51, 3041-3050.

Zhang, G.-L., Chen, L.-H., Jackson, M.G., Hofmann, A., 2017. Evolution of carbonated melt to alkali basalt in the South China Sea. Nat. Geosci. 10, 229-236. 